\title{
A Smart Fluorescent Probe for NO Detection and the Application in Myocardial Fibrosis Imaging
}

Tongliang Zhou,,${ }^{\mathrm{a}, \dagger}$ Junda Wang,,${ }^{\mathrm{a}, \dagger}$ Jiamin $\mathrm{Xu},{ }^{\mathrm{b}}$ Cangxin Zheng, ${ }^{\mathrm{a}}$ Yan Niu, ${ }^{\mathrm{a}}$

Chao Wang, ${ }^{\mathrm{a}}$ Fengrong $\mathrm{Xu},{ }^{\mathrm{a}}$ Lan Yuan, ${ }^{\mathrm{c}}$ Xin Zhao, ${ }^{\text {b }}$ Lei Liang, ${ }^{\text {a a }}$ Ping $\mathrm{Xu}^{* \mathrm{a}}$

${ }^{a}$ Department of Medicinal Chemistry, School of Pharmaceutical Sciences, Peking University, Beijing, China.

${ }^{b}$ Department of Molecular and Cellular Pharmacology, School of Pharmaceutical Sciences, Peking University, Beijing, China.

${ }^{c}$ Medical and Healthy Analysis Center, Peking University, Beijing, China.

$\dagger$ Authors contribute equally to this paper.

\section{Content}

1. Chemical materials and methods

2. Syntheses of probes

3. Photophysical characterization of probes

4. Identification of the reaction products

5. Biological assays of probes

6. NMR and HRMS spectra

7. Reference 


\section{Chemical materials and methods}

Solvents and chemicals were purchased from Alfa Aesar and J\&K and used without further purification, unless specifically mentioned. Reactions were monitored by thin layer chromatography (TLC) using silica gel precoated glass plates with $0.25 \mathrm{~mm}$ thickness (Qingdao Haiyang Chemical, China). The ${ }^{1} \mathrm{H}$ NMR and ${ }^{13} \mathrm{C}$ NMR spectroscopic measurements were carried out using a Bruker Avance III $400 \mathrm{MHz}$ spectrometer. Tetramethylsilane (TMS) is used as the internal reference. Electrospray ionization (ESI) mass spectra were performed on a Waters Xevo G2-XS QTof Quadrupole Time-of-Flight Mass Spectrometry (USA). UV-vis and fluorescence spectra were recorded on a Cary-300 UV-vis spectrophotometer (Agilent Technologies) and a Cary Eclipse fluorescence spectrophotometer (Agilent Technologies), respectively. Quantum yields were measured relative to the fluorescence of rhodamine $\mathrm{B}$ in $\mathrm{MeOH}$. 


\section{Syntheses of probes}

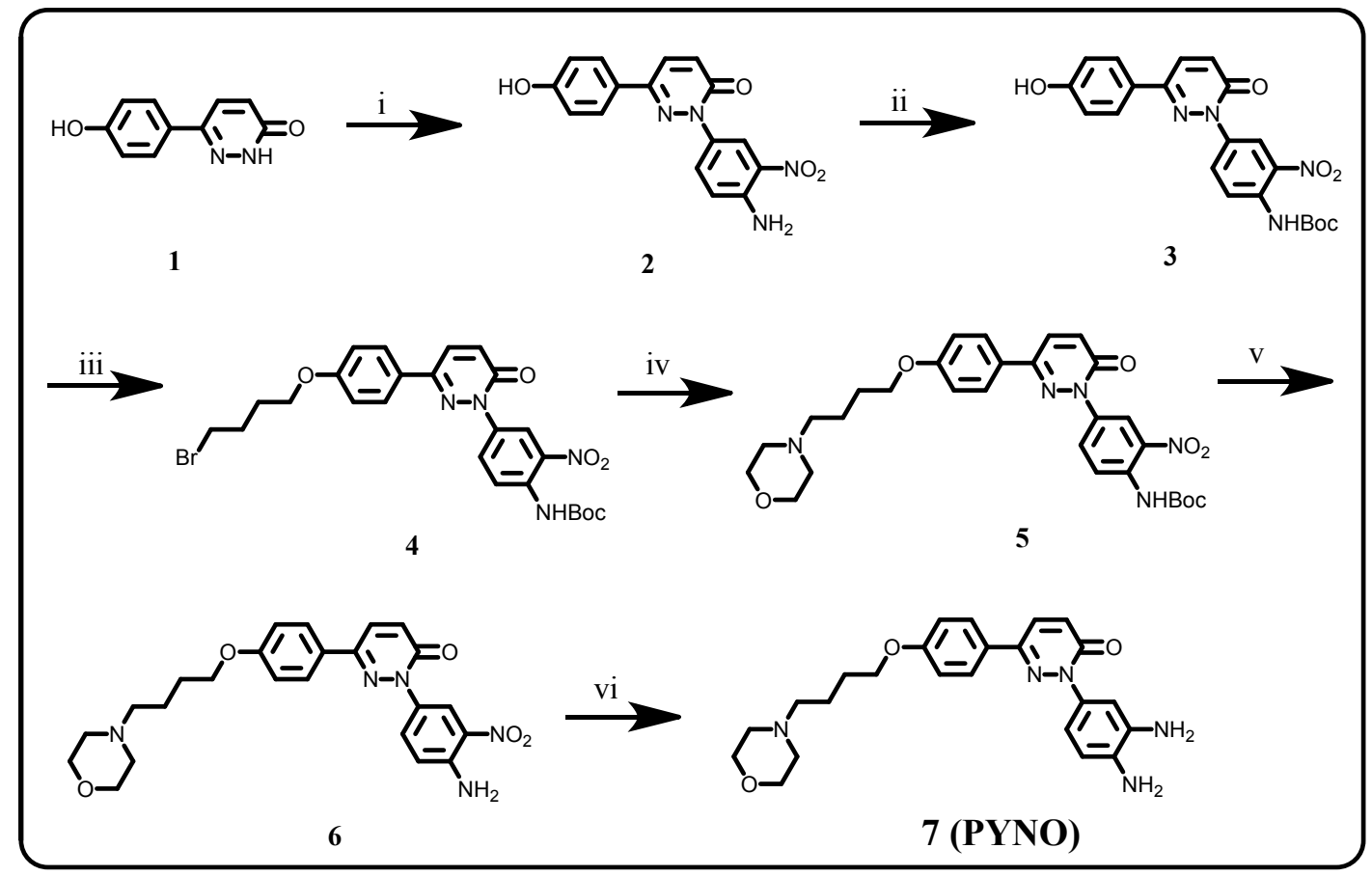

Scheme S1. Structure and synthesis of PYNO.

Reagents and conditions: (i) 4-Bromo-2-nitroaniline, $\mathrm{CuI}, \mathrm{Cs}_{2} \mathrm{CO}_{3}, \mathrm{DMF}, 120^{\circ} \mathrm{C}, 48$ h, $26 \%$; (ii) $\mathrm{Boc}_{2} \mathrm{O}, \mathrm{NaH}, \mathrm{DMF}, 0.5$ h, $49 \%$; (iii) 1,4-dibromobutane, $\mathrm{K}_{2} \mathrm{CO}_{3}, \mathrm{MeCN}$, reflux, 21 h, $72 \%$; (iv) morpholine, $\mathrm{K}_{2} \mathrm{CO}_{3}, \mathrm{MeCN}$, reflux, 16 h, $83 \%$; (v) 25\% TFA/DCM, 3 h, $98 \%$; (vi) 10\% $\mathrm{Pd} / \mathrm{C}, \mathrm{NH}_{2} \mathrm{NH}_{2} \cdot \mathrm{H}_{2} \mathrm{O}$, dioxane, reflux, 6 h, $85 \%$.

Compound 1 was synthesized according to our previous report. ${ }^{1}$

\section{Synthesis of compound 2}

Compound 1 (1.5 g, $10 \mathrm{mmol}$ ), 4-Bromo-2-nitroaniline (1.82 g, $10.5 \mathrm{mmol})$, CuI (2 g, $10.5 \mathrm{mmol})$ and $\mathrm{Cs}_{2} \mathrm{CO}_{3}(6.84 \mathrm{~g}, 21 \mathrm{mmol})$ were added into the Schlenk flask, the mixture were sealed by rubber cap and degassed by Schlenk line with argon. DMF (100 $\mathrm{mL}$ ) was added as solvent, the mixture was then heated to $120^{\circ} \mathrm{C}$ for $48 \mathrm{~h}$. After cooling to room temperature, ammonium hydroxide $(60 \mathrm{~mL})$ was added to the mixture. Then 
the mixture was extracted with ethyl acetate $(3 \times 90 \mathrm{~mL})$ and the combined organic layer was washed by brine $(3 \times 90 \mathrm{~mL})$, dried over anhydrous $\mathrm{Na}_{2} \mathrm{SO}_{4}$, filtered and concentrated under reduced pressure. The residue was purified by column chromatography on silica gel with eluent petroleum/ethyl acetate $(\mathrm{v} / \mathrm{v}, 2: 1)$ to afford yellow solid $2(850 \mathrm{mg}, 26 \%)$.

M.p.: $283 \sim 285{ }^{\circ} \mathrm{C} .{ }^{1} \mathrm{H}$ NMR $\left(400 \mathrm{MHz}, \mathrm{DMSO}-d_{6}\right) \delta 9.88(\mathrm{~s}, 1 \mathrm{H}), 8.31(\mathrm{~d}, J=2.4$ Hz, 1H), $8.04(\mathrm{~d}, J=9.8 \mathrm{~Hz}, 1 \mathrm{H}), 7.79-7.70(\mathrm{~m}, 3 \mathrm{H}), 7.67(\mathrm{~s}, 2 \mathrm{H}), 7.13(\mathrm{~d}, J=3.8$ $\mathrm{Hz}, 1 \mathrm{H}), 7.11(\mathrm{~d}, J=4.4 \mathrm{~Hz}, 1 \mathrm{H}), 6.87(\mathrm{~d}, J=8.3 \mathrm{~Hz}, 2 \mathrm{H}) .{ }^{13} \mathrm{C}$ NMR $(101 \mathrm{MHz}$, DMSO- $\left.d_{6}\right) \delta 158.91,158.47,145.48,144.32,133.10,130.72,129.69,128.91,127.54$, 124.97, 121.77, 119.03, 115.69. HRMS (ESI) $[\mathrm{M}+\mathrm{H}]^{+}$calcd for $\mathrm{C}_{16} \mathrm{H}_{12} \mathrm{~N}_{4} \mathrm{O}_{4} 325.0937$, found 325.0953 .

\section{Synthesis of compound $\mathbf{3}$}

Compound 2 (804 g, $2.48 \mathrm{mmol}$ ) and $\mathrm{NaH}(595 \mathrm{~g}, 60 \% \mathrm{wt}, 14.88 \mathrm{mmol})$ were added into the Schlenk flask, the mixture was sealed by rubber cap and degassed by Schlenk line with argon. DMF (20 mL) was added as solvent, and then di-tert-butyl bicarbonate (541 mg, $2.48 \mathrm{mmol})$ in DMF (10 mL) was added dropwise during 20 minutes period. After the addition, the mixture was stirred for another 30 minutes, then water $(20 \mathrm{~mL})$ was added to quench the reaction. The mixture was extracted with ethyl acetate $(3 \times 50$ $\mathrm{mL})$ and the combined organic layer was washed by brine $(3 \times 60 \mathrm{~mL})$, dried over anhydrous $\mathrm{Na}_{2} \mathrm{SO}_{4}$, filtered and concentrated under reduced pressure. The residue was purified by column chromatography on silica gel with eluent 
dichloromethane/methanol (v/v, 500:1 200:1) to obtain yellow solid 3 (518 mg, $49 \%$ ). M.p.: $205 \sim 207{ }^{\circ} \mathrm{C} .{ }^{1} \mathrm{H}$ NMR (400 MHz, DMSO- $\left.d_{6}\right) \delta 9.91(\mathrm{~s}, 1 \mathrm{H}), 9.76(\mathrm{~s}, 1 \mathrm{H}), 8.36$ $(\mathrm{d}, J=2.7 \mathrm{~Hz}, 1 \mathrm{H}), 8.08(\mathrm{~d}, J=9.8 \mathrm{~Hz}, 1 \mathrm{H}), 8.03(\mathrm{dd}, J=8.9,2.4 \mathrm{~Hz}, 1 \mathrm{H}), 7.83-7.75$ (m, 3H), $7.16(\mathrm{~d}, J=9.8 \mathrm{~Hz}, 1 \mathrm{H}), 6.88(\mathrm{~d}, J=8.5 \mathrm{~Hz}, 2 \mathrm{H}), 1.48(\mathrm{~s}, 9 \mathrm{H}) .{ }^{13} \mathrm{C}$ NMR $(101$ $\left.\mathrm{MHz}, \mathrm{DMSO}-d_{6}\right) \delta 159.07,158.45,152.30,144.73,140.15,136.76,131.89,131.14$ 131.01, 130.89, 127.68, 124.75, 123.78, 121.98, 115.71, 80.75, 27.86. HRMS (ESI) $[\mathrm{M}+\mathrm{H}]^{+}$calcd for $\mathrm{C}_{21} \mathrm{H}_{21} \mathrm{~N}_{4} \mathrm{O}_{6} 425.1461$, found 425.1375 .

\section{Synthesis of compound 4}

In a round-bottom flask, compound $3(620 \mathrm{mg}, 1.46 \mathrm{mmol})$ and 1,4-dibromobutane (378 $\mathrm{mg}, 1.75 \mathrm{mmol})$ were dissolved in acetonitrile $(40 \mathrm{~mL})$, then potassium carbonate (242 $\mathrm{mg}, 1.75 \mathrm{mmol}$ ) was added into the mixture. The resulting mixture was refluxed for $21 \mathrm{~h}$. After cooling, the mixture was filtered, and the filtrate was concentrated under reduced pressure. The residue was purified by column chromatography on silica gel with eluent petroleum/ethyl acetate (v/v, 6:1 3:1) to afford yellow solid 4 (583 mg, 72 $\%)$.

M.p.: $152 \sim 154{ }^{\circ} \mathrm{C} .{ }^{1} \mathrm{H}$ NMR $\left(400 \mathrm{MHz}, \mathrm{CDCl}_{3}\right) \delta 9.76(\mathrm{~s}, 1 \mathrm{H}), 8.71(\mathrm{~d}, J=9.2 \mathrm{~Hz}$, $1 \mathrm{H}), 8.67(\mathrm{~d}, J=2.6 \mathrm{~Hz}, 1 \mathrm{H}), 8.06(\mathrm{dd}, J=9.3,2.6 \mathrm{~Hz}, 1 \mathrm{H}), 7.80-7.68(\mathrm{~m}, 3 \mathrm{H}), 7.12$ $(\mathrm{d}, J=9.8 \mathrm{~Hz}, 1 \mathrm{H}), 6.98(\mathrm{~d}, J=8.9 \mathrm{~Hz}, 2 \mathrm{H}), 4.06(\mathrm{t}, J=5.9 \mathrm{~Hz}, 2 \mathrm{H}), 3.50(\mathrm{t}, J=6.5$ $\mathrm{Hz}, 2 \mathrm{H}), 2.15-2.04(\mathrm{~m}, 2 \mathrm{H}), 2.04-1.93(\mathrm{~m}, 2 \mathrm{H}), 1.56$ (s, 9H). ${ }^{13} \mathrm{C}$ NMR (101 MHz, $\left.\mathrm{CDCl}_{3}\right) \delta 160.53,159.29,152.17,145.33,135.53,135.47,135.42,132.54,131.56$ $130.58,127.67,126.75,122.67,120.70,115.08,82.33,67.17,33.48,29.83,29.51$, 
28.32, 27.93. HRMS (ESI) $[\mathrm{M}+\mathrm{H}]^{+}$calcd for $\mathrm{C}_{25} \mathrm{H}_{28} \mathrm{BrN}_{4} \mathrm{O}_{6} 559.1192,561.1172$ found $559.1119,561.1091$.

\section{Synthesis of compound 5}

In a round-bottom flask, compound $4(112 \mathrm{mg}, 0.2 \mathrm{mmol})$ and morpholine (52 mg, 0.6 mmol) were dissolved in acetonitrile $(10 \mathrm{~mL})$, then potassium carbonate $(42 \mathrm{mg}, 0.3$ mmol) was added into the mixture. The resulting mixture was refluxed for $16 \mathrm{~h}$. After cooling, the mixture was filtered, and the filtrate was concentrated under reduced pressure. The residue was purified by column chromatography on silica gel with eluent dichloromethane/methanol (v/v, 100:1 40:1) to afford yellow solid 5 (94 mg, $83 \%$ ).

M.p.: $100 \sim 102{ }^{\circ} \mathrm{C} .{ }^{1} \mathrm{H}$ NMR $\left(400 \mathrm{MHz}, \mathrm{DMSO}-d_{6}\right) \delta 9.79(\mathrm{~s}, 1 \mathrm{H}), 8.35(\mathrm{~d}, J=2.5$ $\mathrm{Hz}, 1 \mathrm{H}), 8.12(\mathrm{~d}, J=9.9 \mathrm{~Hz}, 1 \mathrm{H}), 8.03(\mathrm{dd}, J=8.9,2.5 \mathrm{~Hz}, 1 \mathrm{H}), 7.91-7.84(\mathrm{~m}, 2 \mathrm{H})$, $7.80(\mathrm{~d}, J=8.9 \mathrm{~Hz}, 1 \mathrm{H}), 7.18(\mathrm{~d}, J=9.8 \mathrm{~Hz}, 1 \mathrm{H}), 7.03(\mathrm{~d}, J=9.0 \mathrm{~Hz}, 2 \mathrm{H}), 4.03(\mathrm{t}, J=$ $6.5 \mathrm{~Hz}, 2 \mathrm{H}), 3.55(\mathrm{t}, J=4.6 \mathrm{~Hz}, 4 \mathrm{H}), 2.40-2.26(\mathrm{~m}, 6 \mathrm{H}), 1.80-1.69(\mathrm{~m}, 2 \mathrm{H}), 1.64-$ $1.52(\mathrm{~m}, 2 \mathrm{H}), 1.47(\mathrm{~s}, 9 \mathrm{H}) .{ }^{13} \mathrm{C}$ NMR $\left(101 \mathrm{MHz}, \mathrm{DMSO}-d_{6}\right) \delta 159.99,158.49,152.33$, $144.45,140.17,136.71,131.95,131.20,131.10,130.92,127.62,126.18,123.78$ 122.04, 114.81, 80.80, 67.49, 66.21, 57.75, 53.30, 27.89, 26.48, 22.33. HRMS (ESI) $[\mathrm{M}+\mathrm{H}]^{+}$calcd for $\mathrm{C}_{29} \mathrm{H}_{36} \mathrm{~N}_{5} \mathrm{O}_{7} 566.2615$ found 566.2624.

\section{Synthesis of compound 6}

In a round-bottom flask, compound $5(112 \mathrm{mg}, 0.2 \mathrm{mmol})$ was dissolved in dichloromethane $(7.5 \mathrm{~mL})$, then trifluoroacetic acid $(2.5 \mathrm{~mL})$ was added into the 
mixture. The resulting mixture was stirred for $2 \mathrm{~h}$, and saturated sodium bicarbonate solution $(20 \mathrm{~mL})$ was added to quench the reaction. The mixture was extracted with dichloromethane $(3 \times 50 \mathrm{~mL})$, and the combined organic layer was washed by brine $(3$ $\times 60 \mathrm{~mL}$ ), dried over anhydrous $\mathrm{Na}_{2} \mathrm{SO}_{4}$, filtered and concentrated under reduced pressure. The residue was purified by column chromatography on silica gel with eluent dichloromethane/methanol (v/v, 50:1 20:1) to afford reddish solid 6 (73 mg, $98 \%$ ).

M.p.: $123 \sim 125{ }^{\circ} \mathrm{C} .{ }^{1} \mathrm{H}$ NMR (400 MHz, DMSO- $\left.d_{6}\right) \delta 8.31(\mathrm{~s}, 1 \mathrm{H}), 8.09(\mathrm{~d}, J=9.8$ $\mathrm{Hz}, 1 \mathrm{H}), 7.85$ (d, $J=8.0 \mathrm{~Hz}, 2 \mathrm{H}), 7.74$ (d, $J=9.2 \mathrm{~Hz}, 1 \mathrm{H}), 7.70(\mathrm{~s}, 2 \mathrm{H}), 7.13$ (d, $J=$ $9.1 \mathrm{~Hz}, 2 \mathrm{H}), 7.03(\mathrm{~d}, J=8.2 \mathrm{~Hz}, 2 \mathrm{H}), 4.03(\mathrm{t}, J=6.5 \mathrm{~Hz}, 2 \mathrm{H}), 3.55(\mathrm{t}, J=4.7 \mathrm{~Hz}, 4 \mathrm{H})$, $2.45-2.22(\mathrm{~m}, 6 \mathrm{H}), 1.74(\mathrm{p}, J=6.9 \mathrm{~Hz}, 2 \mathrm{H}), 1.57(\mathrm{p}, J=7.4 \mathrm{~Hz}, 2 \mathrm{H}) .{ }^{13} \mathrm{C}$ NMR $(101$ MHz, DMSO- $\left.d_{6}\right) \delta 159.87,158.54,145.59,144.06,133.15,130.81,129.64,128.90$, $127.50,126.40,121.85,119.09,114.82,67.49,66.24,57.77,53.32,26.50,22.35$. HRMS (ESI) $[\mathrm{M}+\mathrm{H}]^{+}$calcd for $\mathrm{C}_{24} \mathrm{H}_{28} \mathrm{~N}_{5} \mathrm{O}_{5} 466.2090$ found 466.2099.

\section{Synthesis of compound 7 (PYNO)}

In a three-necked flask, compound 6 (52 $\mathrm{mg}, 0.11 \mathrm{mmol})$ was dissolved in dioxane (10 $\mathrm{mL})$, then $10 \% \mathrm{Pd} / \mathrm{C}(5 \mathrm{mg})$ was added into the mixture. The resulting mixture was added hydrazine hydrate $(110 \mathrm{mg}, 50 \% \mathrm{wt}, 11 \mathrm{mmol})$ dropwise for 15 minutes period at $90{ }^{\circ} \mathrm{C}$ and refluxed for another $6 \mathrm{~h}$ after the addition. After cooling, the mixture was filtered, and the filtrate was concentrated under reduced pressure. The residue was purified by column chromatography on silica gel with eluent dichloromethane/methanol (v/v, 50:1 20:1) to afford red solid PYNO (41 mg, 85 \%). 
M.p.: $85 \sim 87{ }^{\circ} \mathrm{C} .{ }^{1} \mathrm{H}$ NMR $\left(400 \mathrm{MHz}, \mathrm{CDCl}_{3}\right) \delta 7.71(\mathrm{~d}, J=8.3 \mathrm{~Hz}, 2 \mathrm{H}), 7.64(\mathrm{~d}, J=$ 9.7 Hz, 1H), $7.05(\mathrm{~d}, J=10.2 \mathrm{~Hz}, 1 \mathrm{H}), 7.00-6.87(\mathrm{~m}, 4 \mathrm{H}), 6.71(\mathrm{~d}, J=8.2 \mathrm{~Hz}, 1 \mathrm{H})$, $3.99(\mathrm{t}, J=6.4 \mathrm{~Hz}, 2 \mathrm{H}), 3.69(\mathrm{t}, J=4.8 \mathrm{~Hz}, 4 \mathrm{H}), 3.49(\mathrm{~s}, 4 \mathrm{H}), 2.58-2.31(\mathrm{~m}, 6 \mathrm{H}), 1.88$ $-1.73(\mathrm{~m}, 2 \mathrm{H}), 1.73-1.59(\mathrm{~m}, 2 \mathrm{H}) .{ }^{13} \mathrm{C} \mathrm{NMR}\left(101 \mathrm{MHz}, \mathrm{CDCl}_{3}\right) \delta$ 160.15, 159.68, $144.25,135.22,134.66,134.21,130.98,129.74,127.42,127.14,117.29,115.95$, $114.78,113.90,67.78,66.95,58.58,53.70,27.12,23.04$. HRMS (ESI) $[\mathrm{M}+\mathrm{H}]^{+}$calcd for $\mathrm{C}_{24} \mathrm{H}_{30} \mathrm{~N}_{5} \mathrm{O}_{3} 436.2349$ found 436.2346 . 


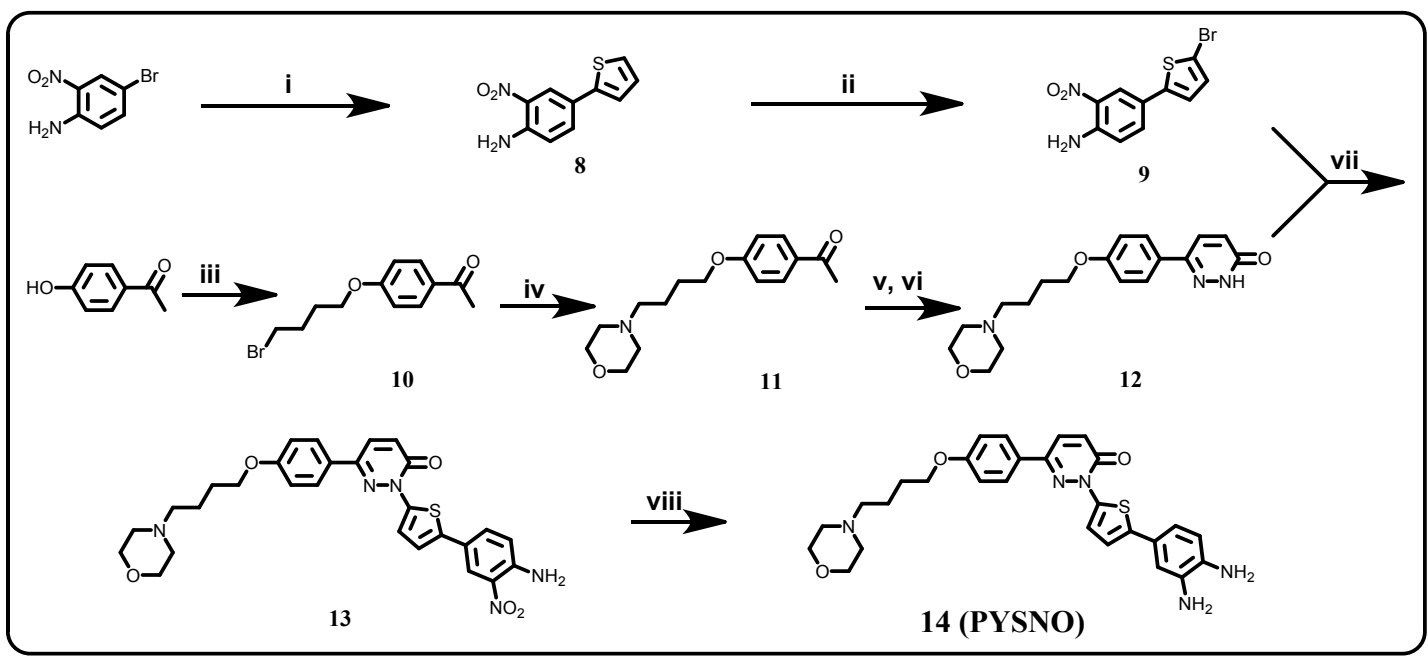

Scheme S2. Structure and synthesis of PYSNO.

Reagents and conditions: (i)2-thienylboronic acid, $\mathrm{Pd}\left(\mathrm{PPh}_{3}\right)_{4}, \mathrm{~K}_{2} \mathrm{CO}_{3}, \mathrm{DMF}, \mathrm{H}_{2} \mathrm{O}, 100$ ${ }^{\circ} \mathrm{C}, 12$ h, $50 \%$; (ii) NBS, THF, r. t., 12 h, $72 \%$; (iii) 1,4-Dibromobutane, $\mathrm{K}_{2} \mathrm{CO}_{3}, \mathrm{MeCN}$, reflux, 24 h, $80 \%$; (iv) morpholine, $\mathrm{K}_{2} \mathrm{CO}_{3}, \mathrm{MeCN}$, reflux, 20 h, $92 \%$; (v) glyoxalic acid monohydrate, $\mathrm{AcOH}, 110{ }^{\circ} \mathrm{C}, 3 \mathrm{~h}$; (vi) $\mathrm{NH}_{2} \mathrm{NH}_{2} \cdot \mathrm{H}_{2} \mathrm{O}, 100{ }^{\circ} \mathrm{C}, 20 \mathrm{~h}, 62 \%$; (vii) $\mathrm{CuI}, \mathrm{Cs}_{2} \mathrm{CO}_{3}, \mathrm{~N}, \mathrm{~N}^{\prime}$-dimethylethanediamine, DMF, $120^{\circ} \mathrm{C}, 60 \mathrm{~h}, 33 \%$; (viii) $10 \% \mathrm{Pd} / \mathrm{C}$, $\mathrm{NH}_{2} \mathrm{NH}_{2} \cdot \mathrm{H}_{2} \mathrm{O}$, dioxane, reflux, $6 \mathrm{~h}, 76 \%$.

\section{Synthesis of compound $\mathbf{8}$}

A Schlenk flask containing $\mathrm{Pd}\left(\mathrm{PPh}_{3}\right)_{4}(289 \mathrm{mg}, 0.25 \mathrm{mmol})$ was degassed for $10 \mathrm{~min}$ before injecting Argon (repeated 3 times). 4-Bromo-2-nitroaniline (1.08 g, $5 \mathrm{mmol}$ ) and thiophen-2-ylboronic acid (768 mg, $6 \mathrm{mmol})$ in DMF (10 mL), $\mathrm{K}_{2} \mathrm{CO}_{3}(2.76 \mathrm{~g}, 20 \mathrm{mmol})$ in water $(10 \mathrm{~mL})$ were injected by syringe and kept at $90{ }^{\circ} \mathrm{C}$ for $12 \mathrm{~h}$ under $\mathrm{Ar}$ atmosphere. After the solvents were removed, water $(20 \mathrm{ml})$ was added and the mixture was extracted with ethyl acetate $(3 \times 50 \mathrm{~mL})$. The organic layer was washed sequentially with $\mathrm{H}_{2} \mathrm{O}(2 \times 50 \mathrm{~mL})$ and brine $(1 \times 50 \mathrm{~mL})$, dried over anhydrous $\mathrm{Na}_{2} \mathrm{SO}_{4}$, filtered and concentrated under reduced pressure. The obtained crude product was 
purified with column chromatography on silica gel with petroleum/ethyl acetate $(\mathrm{v} / \mathrm{v}$, $8: 1)$ to afford red powder $8(550 \mathrm{mg}, 50 \%)$.

M.p.: $73 \sim 75{ }^{\circ} \mathrm{C} .{ }^{1} \mathrm{H}$ NMR $\left(400 \mathrm{MHz}, \mathrm{DMSO}-d_{6}\right) \delta 8.13(\mathrm{~d}, J=2.2 \mathrm{~Hz}, 1 \mathrm{H}), 7.75(\mathrm{dd}$, $J=8.9,2.3 \mathrm{~Hz}, 1 \mathrm{H}), 7.62(\mathrm{~s}, 2 \mathrm{H}), 7.47(\mathrm{dd}, J=5.1,1.1 \mathrm{~Hz}, 1 \mathrm{H}), 7.42(\mathrm{dd}, J=3.6,1.1$ $\mathrm{Hz}, 1 \mathrm{H}), 7.12-7.06(\mathrm{~m}, 2 \mathrm{H}) .{ }^{13} \mathrm{C} \mathrm{NMR}\left(101 \mathrm{MHz}, \mathrm{DMSO}-d_{6}\right) \delta 145.58,141.89,133.34$, 129.93, 128.50, 124.64, 122.85, 121.59, 120.91, 120.19. HRMS (ESI) [M-H]- calcd for $\mathrm{C}_{10} \mathrm{H}_{7} \mathrm{~N}_{2} \mathrm{O}_{2} \mathrm{~S} 219.0228$ found 219.0229 .

\section{Synthesis of compound 9}

In a THF $(20 \mathrm{~mL})$ solution of compound $8(440 \mathrm{mg}, 2 \mathrm{mmol})$ at $0{ }^{\circ} \mathrm{C}$, a THF $(10 \mathrm{~mL})$ solution of N-bromosuccinimide (374 mg, $2.1 \mathrm{mmol}$ ) was added dropwise. The mixture was stirred at room temperature for $12 \mathrm{~h}$. Then the mixture was diluted by saturated sodium thiosulfate solution. The mixture was extracted with ethyl acetate $(3 \times 70 \mathrm{~mL})$ and the combined organic layer was washed by brine $(2 \times 50 \mathrm{~mL})$, dried over anhydrous $\mathrm{Na}_{2} \mathrm{SO}_{4}$, filtered and concentrated under reduced pressure. The crude product was purified by chromatography on silica gel with eluent petroleum/ethyl acetate (v/v, 7:1). to afford red powder $9(428 \mathrm{mg}, 72 \%)$.

M.p.: $85 \sim 87{ }^{\circ} \mathrm{C} .{ }^{1} \mathrm{H}$ NMR $\left(400 \mathrm{MHz}, \mathrm{DMSO}-d_{6}\right) \delta 8.07(\mathrm{~d}, J=2.3 \mathrm{~Hz}, 1 \mathrm{H}), 7.69(\mathrm{dd}$, $J=8.9,2.3 \mathrm{~Hz}, 1 \mathrm{H}), 7.66(\mathrm{~s}, 2 \mathrm{H}), 7.26(\mathrm{~d}, J=3.9 \mathrm{~Hz}, 1 \mathrm{H}), 7.21(\mathrm{~d}, J=3.9 \mathrm{~Hz}, 1 \mathrm{H})$, $7.07(\mathrm{~d}, J=8.9 \mathrm{~Hz}, 1 \mathrm{H}) .{ }^{13} \mathrm{C} \mathrm{NMR}\left(101 \mathrm{MHz}, \mathrm{DMSO}-d_{6}\right) \delta 145.82,143.65,132.94$, 131.68, 129.91, 123.47, 121.09, 120.53, 120.27, 109.27. HRMS (ESI) [M-H]- calcd for $\mathrm{C}_{10} \mathrm{H}_{6} \mathrm{BrN}_{2} \mathrm{O}_{2} \mathrm{~S} 296.9333,298.9313$ found 296.9330, 298.9315. 


\section{Synthesis of compound $\mathbf{1 0}$}

In a round-bottom flask, 4'-Hydroxyacetophenone (2.04 g, $15 \mathrm{mmol})$ and 1,4dibromobutane $(6.48 \mathrm{~g}, 30 \mathrm{mmol})$ were dissolved in acetonitrile $(20 \mathrm{~mL})$, then potassium carbonate $(6.22 \mathrm{~g}, 45 \mathrm{mmol})$ was added into the mixture. The resulting mixture was refluxed for $36 \mathrm{~h}$. After cooling, the mixture was filtered, and the filtrate was concentrated under reduced pressure. The residue was purified by column chromatography on silica gel with eluent petroleum/ethyl acetate $(\mathrm{v} / \mathrm{v}, 10: 1 \sim 4: 1)$ to afford colorless oil $\mathbf{1 0}(3.25 \mathrm{~g}, 80 \%)$.

${ }^{1} \mathrm{H}$ NMR $\left(400 \mathrm{MHz}, \mathrm{CDCl}_{3}\right) \delta 7.93(\mathrm{~d}, J=8.8 \mathrm{~Hz}, 2 \mathrm{H}), 6.91(\mathrm{~d}, J=8.8 \mathrm{~Hz}, 2 \mathrm{H}), 4.06$ $(\mathrm{t}, J=6.0 \mathrm{~Hz}, 2 \mathrm{H}), 3.49(\mathrm{t}, J=6.5 \mathrm{~Hz}, 2 \mathrm{H}), 2.55(\mathrm{~s}, 3 \mathrm{H}), 2.08(\mathrm{p}, J=6.6 \mathrm{~Hz}, 2 \mathrm{H}), 1.98$ $(\mathrm{p}, J=6.1 \mathrm{~Hz}, 2 \mathrm{H}) .{ }^{13} \mathrm{C} \mathrm{NMR}\left(101 \mathrm{MHz}, \mathrm{CDCl}_{3}\right) \delta 196.92,162.89,130.73,130.46$, 114.21, 67.19, 33.39, 29.43, 27.83, 26.46. HRMS (ESI) $[\mathrm{M}+\mathrm{H}]^{+}$calcd for $\mathrm{C}_{12} \mathrm{H}_{16} \mathrm{BrO}_{2}$ 271.0334 found 271.0364 .

\section{Synthesis of compound $\mathbf{1 1}$}

In a round-bottom flask, compound $10(2.71 \mathrm{~g}, 10 \mathrm{mmol})$ and morpholine $(1.74 \mathrm{~g}, 20$ mmol) were dissolved in acetonitrile $(40 \mathrm{~mL})$, then potassium carbonate $(4.15 \mathrm{~g}, 30$ mmol) was added into the mixture. The resulting mixture was refluxed for $20 \mathrm{~h}$. After cooling, the mixture was filtered, and the filtrate was concentrated under reduced pressure. The residue was purified by column chromatography on silica gel with eluent dichloromethane/methanol (v/v, 100:1 50:1) to afford off white solid 11 (2.55 g, $92 \%)$. 
M.p.: $65 \sim 68{ }^{\circ} \mathrm{C} .{ }^{13} \mathrm{C} \mathrm{NMR}\left(101 \mathrm{MHz}, \mathrm{CDCl}_{3}\right) \delta 196.78,163.00,130.61,130.22$, 114.14, 67.93, 67.02, 58.55, 53.75, 27.05, 26.36, 23.04. HRMS (ESI) $[\mathrm{M}+\mathrm{H}]^{+}$calcd for $\mathrm{C}_{16} \mathrm{H}_{24} \mathrm{NO}_{3} 278.1756$ found 278.1792. $\left.{ }^{13} \mathrm{C} \mathrm{NMR} \mathrm{(101} \mathrm{MHz,} \mathrm{CDCl}_{3}\right) \delta 196.78$, 163.00, 130.61, 130.22, 114.14, 67.93, 67.02, 58.55, 53.75, 27.05, 26.36, 23.04. HRMS (ESI) $[\mathrm{M}+\mathrm{H}]^{+}$calcd for $\mathrm{C}_{16} \mathrm{H}_{24} \mathrm{NO}_{3} 278.1756$ found 278.1792 .

\section{Synthesis of compound $\mathbf{1 2}$}

Compound 11 (2. $22 \mathrm{~g}, 8 \mathrm{mmol})$, glyoxalic acid monohydrate (1.47 g, $16 \mathrm{mmol})$, and acetic acid $(10 \mathrm{~mL})$ were mixed in a round-bottom flask. The mixture was heated at 110 ${ }^{\circ} \mathrm{C}$ for $3 \mathrm{~h}$, cooled to $0{ }^{\circ} \mathrm{C}$, and then diluted with water $(20 \mathrm{~mL})$. The $\mathrm{pH}$ of the mixture was adjusted to 7 with ammonium hydroxide, and hydrazine hydrate (4 g, $40 \mathrm{mmol}$ ) was added to the solution. Then the mixture was heated at $100{ }^{\circ} \mathrm{C}$ for $20 \mathrm{~h}$. The mixture was cooled to room temperature, extracted with ethyl acetate $(3 \times 70 \mathrm{~mL})$. The combined organic layer was washed by brine $(2 \times 50 \mathrm{~mL})$, dried over anhydrous $\mathrm{Na}_{2} \mathrm{SO}_{4}$, filtered and concentrated under reduced pressure. The crude product was purified by chromatography on silica gel with eluent dichloromethane/methanol (v/v, 50:1 10:1) to afford red white solid $12(1.63 \mathrm{~g}, 62 \%)$.

M.p.: $155 \sim 157{ }^{\circ} \mathrm{C} .{ }^{1} \mathrm{H}$ NMR $\left(400 \mathrm{MHz}, \mathrm{CDCl}_{3}\right) \delta 12.95(\mathrm{~s}, 1 \mathrm{H}), 7.73$ - $7.64(\mathrm{~m}, 3 \mathrm{H})$, $7.02(\mathrm{~d}, J=9.8 \mathrm{~Hz}, 1 \mathrm{H}), 6.91(\mathrm{~d}, J=8.4 \mathrm{~Hz}, 2 \mathrm{H}), 3.99(\mathrm{t}, J=6.3 \mathrm{~Hz}, 2 \mathrm{H}), 3.71(\mathrm{t}, J=$ $4.6 \mathrm{~Hz}, 4 \mathrm{H}), 2.45(\mathrm{t}, J=4.5 \mathrm{~Hz}, 4 \mathrm{H}), 2.40(\mathrm{t}, J=7.6 \mathrm{~Hz}, 2 \mathrm{H}), 1.81(\mathrm{p}, J=6.8 \mathrm{~Hz}, 2 \mathrm{H})$, $1.67(\mathrm{p}, J=7.6 \mathrm{~Hz}, 2 \mathrm{H}) .{ }^{13} \mathrm{C} \mathrm{NMR}\left(101 \mathrm{MHz}, \mathrm{CDCl}_{3}\right) \delta 161.93,160.23,145.30,131.36$,

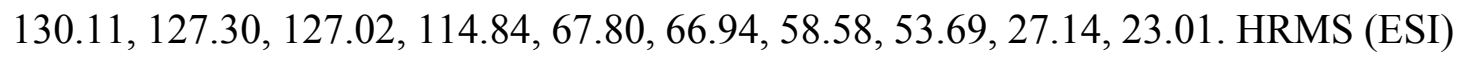


$[\mathrm{M}+\mathrm{H}]^{+}$calcd for $\mathrm{C}_{18} \mathrm{H}_{24} \mathrm{~N}_{3} \mathrm{O}_{3} 330.1818$ found 330.1852 .

\section{Synthesis of compound $\mathbf{1 3}$}

Compound 9 (684 mg, $3.15 \mathrm{mmol}$ ), compound 12 (990 mg, 3 mmol), CuI (600 mg, $3.15 \mathrm{mmol}), \mathrm{Cs}_{2} \mathrm{CO}_{3}(2.05 \mathrm{~g}, 6.3 \mathrm{mmol})$ and N,N'-dimethylethanediamine (26 mg, 0.3 mmol) were added into the Schlenk flask, the mixture were sealed by rubber cap and degassed by Schlenk line with argon. DMF $(30 \mathrm{~mL})$ was added as solvent, the mixture were then heated to $120{ }^{\circ} \mathrm{C}$ for $60 \mathrm{~h}$. After cooling to room temperature, ammonium hydroxide $(30 \mathrm{~mL})$ was added to the mixture. Then the mixture was extracted with ethyl acetate $(3 \times 60 \mathrm{~mL})$ and the combined organic layer was washed by brine $(3 \times 60 \mathrm{~mL})$, dried over anhydrous $\mathrm{Na}_{2} \mathrm{SO}_{4}$, filtered and concentrated under reduced pressure. The residue was purified by column chromatography on silica gel with eluent dichloromethane/methanol (v/v, 100:1 20:1) to afford red solid 13 (548 mg, $33 \%$ ).

M.p.: $224 \sim 226{ }^{\circ} \mathrm{C} .{ }^{1} \mathrm{H}$ NMR $\left(400 \mathrm{MHz}, \mathrm{DMSO}-d_{6}\right) \delta 8.19-8.13(\mathrm{~m}, 2 \mathrm{H}), 8.00(\mathrm{~d}, J$ $=8.9 \mathrm{~Hz}, 2 \mathrm{H}), 7.81(\mathrm{dd}, J=8.8,2.3 \mathrm{~Hz}, 1 \mathrm{H}), 7.78(\mathrm{~d}, J=4.2 \mathrm{~Hz}, 1 \mathrm{H}), 7.66(\mathrm{~s}, 2 \mathrm{H})$, $7.40(\mathrm{~d}, J=4.1 \mathrm{~Hz}, 1 \mathrm{H}), 7.27(\mathrm{~d}, J=9.8 \mathrm{~Hz}, 1 \mathrm{H}), 7.13-7.08(\mathrm{~m}, 3 \mathrm{H}), 4.08(\mathrm{t}, J=6.5$ $\mathrm{Hz}, 3 \mathrm{H}), 3.63-3.53(\mathrm{~m}, 4 \mathrm{H}), 2.42-2.28(\mathrm{~m}, 6 \mathrm{H}), 1.81-1.69(\mathrm{~m}, 2 \mathrm{H}), 1.65-1.55(\mathrm{~m}$, 2H). HRMS (ESI) $[\mathrm{M}+\mathrm{H}]^{+}$calcd for $\mathrm{C}_{28} \mathrm{H}_{30} \mathrm{~N}_{5} \mathrm{O}_{5} \mathrm{~S} 548.1968$ found 548.2015.

\section{Synthesis of compound 14 (PYSNO)}

In a three-necked flask, compound $13(274 \mathrm{mg}, 0.5 \mathrm{mmol})$ was dissolved in dioxane $(20 \mathrm{~mL})$, then $10 \% \mathrm{Pd} / \mathrm{C}(27 \mathrm{mg})$ was added into the mixture. The resulting mixture 
was added hydrazine hydrate (500 mg, $50 \% \mathrm{wt}, 5 \mathrm{mmol})$ dropwise during 15 minutes period at $90^{\circ} \mathrm{C}$ and refluxed for another $6 \mathrm{~h}$ after the addition. After cooling, the mixture was filtered, and the filtrate was concentrated under reduced pressure. The residue was purified by column chromatography on silica gel with eluent dichloromethane/methanol (v/v, 40:1 15:1) to afford red solid PYSNO (197 mg, $76 \%$ ). M.p.: $143 \sim 145{ }^{\circ} \mathrm{C} .{ }^{1} \mathrm{H}$ NMR $\left(400 \mathrm{MHz}, \mathrm{CDCl}_{3}\right) \delta 7.85-7.79(\mathrm{~m}, 3 \mathrm{H}), 7.65(\mathrm{~d}, J=$ $9.8 \mathrm{~Hz}, 1 \mathrm{H}), 7.11(\mathrm{~d}, J=9.6 \mathrm{~Hz}, 1 \mathrm{H}), 7.07$ (d, $J=4.1 \mathrm{~Hz}, 1 \mathrm{H}), 7.03$ (dd, $J=7.9,2.0$ $\mathrm{Hz}, 1 \mathrm{H}), 7.02-6.96(\mathrm{~m}, 3 \mathrm{H}), 6.71(\mathrm{~d}, J=7.9 \mathrm{~Hz}, 1 \mathrm{H}), 4.04(\mathrm{t}, J=6.3 \mathrm{~Hz}, 2 \mathrm{H}), 3.73(\mathrm{t}$, $J=4.7 \mathrm{~Hz}, 4 \mathrm{H}), 3.49(\mathrm{~s}, 4 \mathrm{H}), 2.48(\mathrm{t}, J=4.5 \mathrm{~Hz}, 4 \mathrm{H}), 2.43(\mathrm{t}, J=7.5 \mathrm{~Hz}, 2 \mathrm{H}), 1.84(\mathrm{p}$, $J=6.6 \mathrm{~Hz}, 2 \mathrm{H}), 1.71(\mathrm{p}, J=6.7 \mathrm{~Hz}, 2 \mathrm{H}) .{ }^{13} \mathrm{C} \mathrm{NMR}\left(101 \mathrm{MHz}, \mathrm{CDCl}_{3}\right) \delta 160.63$, $157.13,144.55,141.36,141.22,135.03,134.94,130.67,128.74,127.78,126.75$, $126.52,119.85,119.16,118.10,116.95,115.04,114.22,67.93,67.03,58.67,53.80$, 27.20, 23.12. HRMS (ESI) $[\mathrm{M}+\mathrm{H}]^{+}$calcd for $\mathrm{C}_{28} \mathrm{H}_{32} \mathrm{~N}_{5} \mathrm{O}_{3} \mathrm{~S} 518.2226$ found 518.2217 


\section{Photophysical characterization of probes}

\section{Preparation of sample solutions}

Stock solutions $(10 \mathrm{mM})$ of the probes were prepared in DMSO, and then diluted to the corresponding concentration with $10 \mathrm{mM}$ PBS buffer (pH7.4, containing $10 \% \mathrm{CH}_{3} \mathrm{CN}$ as co-solvent). Various analytes were prepared according to previous report. ${ }^{2,3}$

(1) Peroxynitrite $\left(\mathrm{ONOO}^{-}\right)$

Briefly, hydrochloric acid $(0.6 \mathrm{M}, 10 \mathrm{~mL})$ solution was added to a vigorously stirred solution of sodium nitrite $(0.6 \mathrm{M}, 10 \mathrm{~mL})$ and hydrogen peroxide $(0.7 \mathrm{M}, 10 \mathrm{~mL})$, and then sodium hydroxide $(1.5 \mathrm{M}, 20 \mathrm{~mL})$ was added rapidly to make the solution alkaline. The solution was allowed to pass through a short column of manganese dioxide to eliminate the excess hydrogen peroxide. The resulting solution was split into small aliquots and stored at $-20^{\circ} \mathrm{C}$. The aliquots were thawed immediately before use, and the concentration of peroxynitrite was determined by measuring the absorption of the solution at $302 \mathrm{~nm}$. The extinction coefficient of peroxynitrite solution in $0.1 \mathrm{M} \mathrm{NaOH}$ is $1670 \mathrm{M}^{-1} \mathrm{~cm}^{-1}$ at $302 \mathrm{~nm}^{2}$

(2) hydrogen peroxide $\left(\mathrm{H}_{2} \mathrm{O}_{2}\right)$

Hydrogen peroxide were prepared by diluting commercial $\mathrm{H}_{2} \mathrm{O}_{2}$ solution with PBS (10 mM, pH 7.4, containing $10 \% \mathrm{CH}_{3} \mathrm{CN}$ ). The concentration of the $\mathrm{H}_{2} \mathrm{O}_{2}$ stock solution was determined by measuring the absorbance at $240 \mathrm{~nm}$ with a molar extinction coefficient of $43.6 \mathrm{M}^{-1} \mathrm{~cm}^{-1}$.

(3) Hydroxyl radical $(\mathrm{HO} \bullet)^{3}$ 
Hydroxyl radical was generated in situ by the Fenton reaction. To a solution of $\mathrm{H}_{2} \mathrm{O}_{2}$ $(1.0 \mathrm{mM}, 1.0 \mathrm{~mL})$ was added $\mathrm{FeSO}_{4}$ solution $(1.0 \mathrm{mM}, 100 \mu \mathrm{L})$ at ambient temperature. The concentration of $\bullet \mathrm{OH}$ was equal to the $\mathrm{Fe}(\mathrm{II})$ concentration $(0.1 \mathrm{mM})$.

(4) Hydrogen sulfide $\left(\mathrm{H}_{2} \mathrm{~S}\right)$

Commercially available sodium hydrosulfide (NaHS) was dissolved in PBS to make a stock solution of $\mathrm{H}_{2} \mathrm{~S}$.

Other analyses were freshly prepared with corresponding commercially available reagents.

\section{Fluorescence titration}

$5 \mathrm{~mL}$ of $10 \mu \mathrm{M}$ probes in $10 \mathrm{mM}$ PBS buffer (pH7.4, containing $20 \% \mathrm{CH}_{3} \mathrm{CN}$ as cosolvent) were mixed with an equal volume of various concentrations of NO solution (PBS buffer, $10 \mathrm{mM}, \mathrm{pH} 7.4$ ) in a $10 \mathrm{~mL}$ centrifuge tubes. The tubes were then kept in a dark room for 10 min before measurement of emission spectra.

\section{Quantum yields determination}

Quantum yields were determined using rhodamine $\mathrm{B}(\Phi=0.72$, in $\mathrm{MeOH})$ as a reference according to a published method. ${ }^{1}$ Probes or reference stock solutions (10 $\mathrm{mM}$ ) were prepared by accurately weighing and dissolving the samples in DMSO. For probes before and after the treatment of excess $\mathrm{NO}$, and rhodamine $\mathrm{B}$, testing solutions for measuring UV absorbance and fluorescence were prepared by further dilution of the stock solutions with $10 \mathrm{mM}$ PBS buffer (pH 7.4, containing $10 \% \mathrm{CH}_{3} \mathrm{CN}$ ) or $\mathrm{MeOH}$ to 
$1 \mu \mathrm{M}, 0.8 \mu \mathrm{M}, 0.6 \mu \mathrm{M}, 0.4 \mu \mathrm{M}, 0.2 \mu \mathrm{M}$. The quantum yields of the probes were estimated by comparison of the integrated area of the corrected emission spectrum of the sample with that of the reference solution. The quantum yield was calculated according to the equation: ${ }^{4}$

$$
\Phi_{\text {sample }}=\Phi_{\text {ref }} \cdot \frac{O D_{\text {ref }} \cdot I_{\text {sample }} \cdot \eta_{\text {sample }}^{2}}{O D_{\text {sample }} \cdot I_{\text {ref }} \cdot \eta_{\text {ref }}^{2}}
$$

where $\Phi$ is the quantum yield, I is the integrated fluorescence intensity, OD is absorbance at the excitation wavelength, and $\eta$ represents the refractive index of the solvent.

Table S1. Photophysical data for PYNO and PYSNO before and after reacting with excess NO in PBS solution.

\begin{tabular}{|c|c|c|c|c|}
\hline Compd. $^{[\mathrm{a}]}$ & $\varepsilon^{[\mathrm{b}]}$ & $\lambda^{\mathrm{ex}}{ }_{\max }^{[\mathrm{c}]}$ & $\lambda^{\mathrm{em}}{ }_{\max }^{[\mathrm{d}]}$ & $\Phi^{[\mathrm{e}]}$ \\
\hline PYNO & $0.6 \times 10^{4}$ & 327 & 366 & 0.0025 \\
\hline PYNO+NO & $0.7 \times 10^{4}$ & 327 & 481 & 0.21 \\
\hline PYSNO & $0.5 \times 10^{4}$ & 402 & 581 & 0.0112 \\
\hline PYSNO+NO & $0.4 \times 10^{4}$ & 402 & 548 & 0.28 \\
\hline
\end{tabular}

[a] All data were measured in $10 \mathrm{mM}$ PBS ( $\mathrm{pH}=7.4$, containing $10 \% \mathrm{CH}_{3} \mathrm{CN}$ as cosolvent) in the absence and presence of excess NO. [b] Molar extinction coefficient in $\mathrm{M}^{-1} \mathrm{~cm}^{-1}$ [c, d] $\lambda_{\max }$ of the absorption and emission spectra in $\mathrm{nm}$. [e] Fluorescence quantum yield.

\section{Determination of the limit of detection (LOD)}

According to literature report, the limit of detection was calculated based on the fluorescence titration in the presence of NO. ${ }^{5}$ Firstly, the fluorescence intensity at 
maximal emission (481 nm for PYNO, $548 \mathrm{~nm}$ for PYSNO) at low concentration was plotted versus NO concentration, bringing about the regression curve. Then, the fluorescence emission spectrum of probe was measured by five times and the standard deviation of blank measurement at maximal emission was achieved. The limit of detection was calculated using the following equation:

$$
\text { Limit of detection }(\mathrm{LOD})=3 \sigma / \mathrm{k}
$$

where $\sigma$ is the standard deviation of the blank measurement, and $\mathrm{k}$ is the slope of the regression curve.

\section{Selectivity}

$5 \mathrm{~mL}$ of $10 \mu \mathrm{M}$ probes in $10 \mathrm{mM}$ PBS buffer (pH7.4, containing $10 \% \mathrm{CH}_{3} \mathrm{CN}$ as cosolvent) were mixed with an equal volume of various analyses $(1 \mathrm{mM})$ in a $10 \mathrm{~mL}$ centrifuge tubes. The tubes were then kept in a dark room for $30 \mathrm{~min}$ before measurement of emission spectra.

\section{pH effect}

The fluorescence spectra of probes PYNO and PYSNO in the absence and presence of excess NO in $10 \mathrm{mM}$ PBS buffer (containing $10 \% \mathrm{CH}_{3} \mathrm{CN}$ as co-solvent) of different $\mathrm{pH}$ are recorded. The fluorescence intensities at maximal emission (481 nm for PYNO, $548 \mathrm{~nm}$ for PYSNO) are taken for the following plots. 

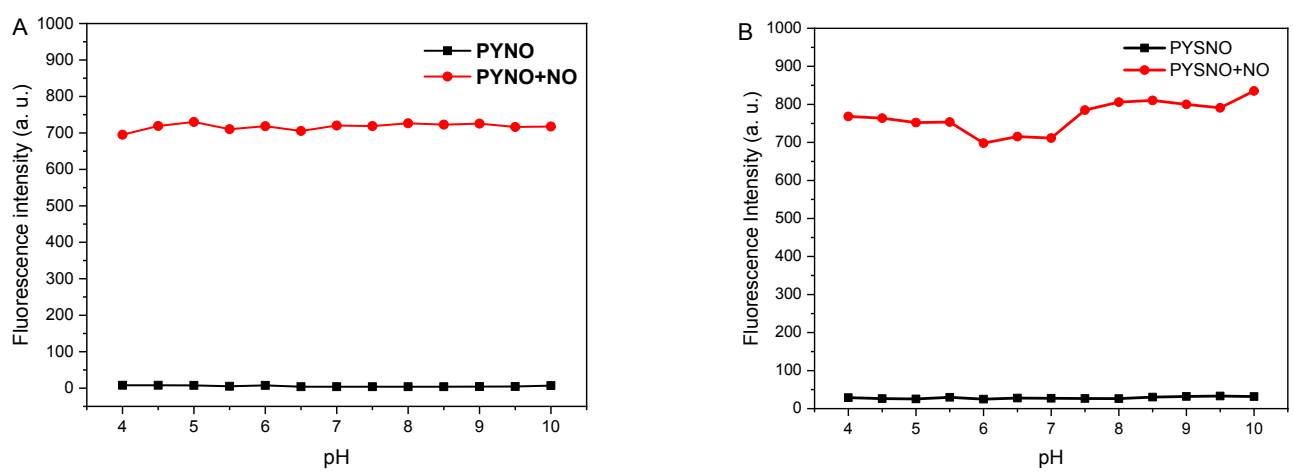

Figure S1. Effect of $\mathrm{pH}$ on the fluorescence intensity of $5 \mu \mathrm{M}$ PYNO and PYSNO in the absence and presence of $50 \mu \mathrm{M}$ NO. All data were measured in $10 \mathrm{mM}$ PBS buffer ( $\mathrm{pH}=7.4$, containing $10 \% \mathrm{CH}_{3} \mathrm{CN}$ as co-solvent) at $25^{\circ} \mathrm{C} . \lambda_{\mathrm{ex}} / \lambda_{\mathrm{em}}=327 / 481 \mathrm{~nm}$ for PYNO and $\lambda_{\mathrm{ex}} / \lambda_{\mathrm{em}}=402 / 548 \mathrm{~nm}$ for PYSNO. 


\section{Identification of the reaction products}

PYNO or PYSNO $(1.0 \mathrm{mg})$ was dissolved in $\mathrm{CH}_{3} \mathrm{CN}(0.5 \mathrm{~mL})$ and $\mathrm{H}_{2} \mathrm{O}(0.5 \mathrm{~mL})$ and treated with excess NO. The resulting solutions were sent to HPLC and HRMS determination immediately.
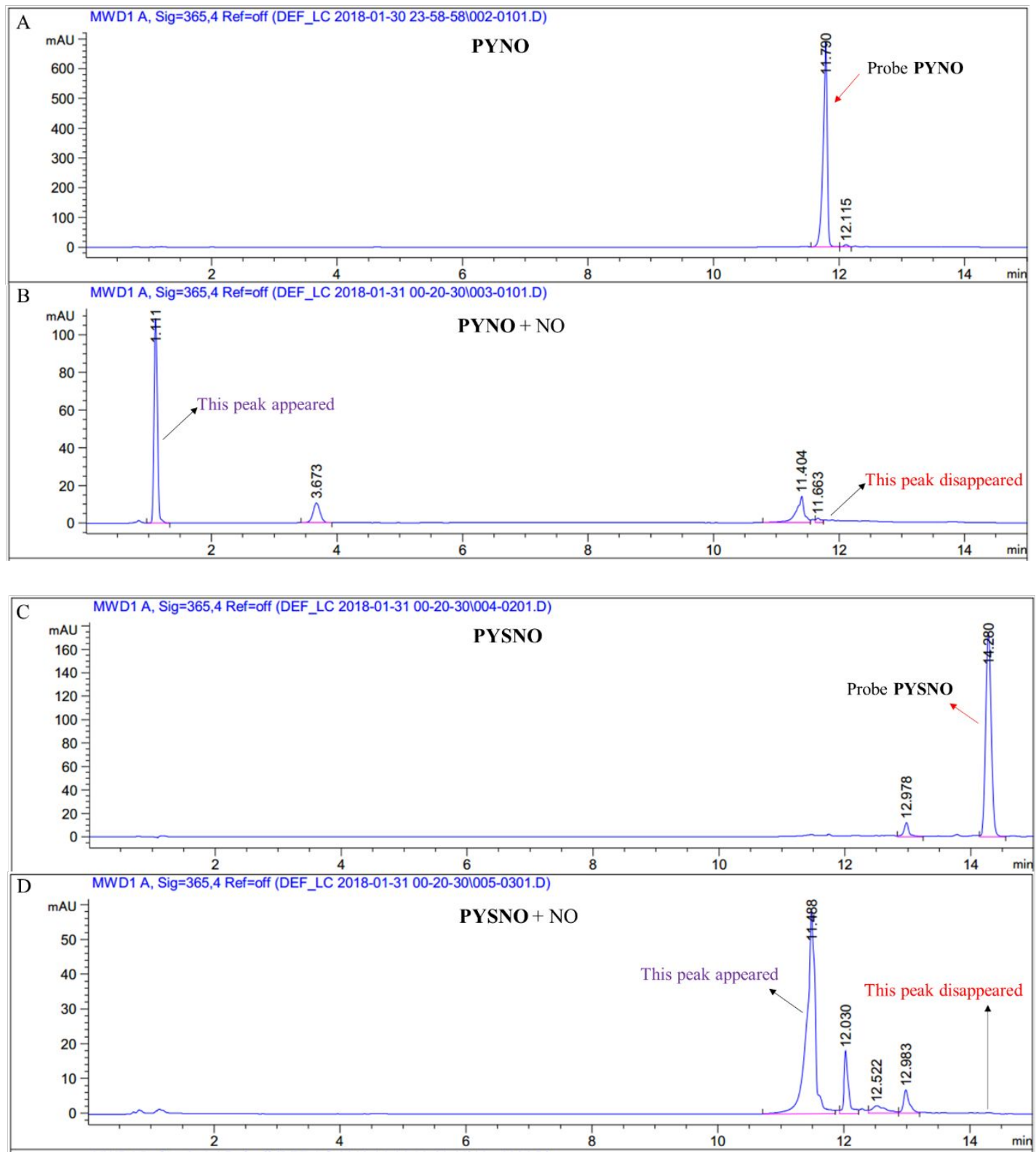

Figure S2. The results of HPLC analyses. (A) Chromatogram of probe PYNO without NO showing a retention time of $11.790 \mathrm{~min}$. (B) Chromatogram of PYNO after reacting with excess NO, demonstrating the disappearance of the original probe and the appearance of a new peak at $1.111 \mathrm{~min}$. (C) Chromatogram of probe PYSNO showing 
a peaking at 14.280 min. (D) Chromatogram of PYSNO in the presence of excess NO, demonstrating the disappearance of the original probe and the appearance of a new peak at 11.488 min. Column: Eclipse Plus C18 column $(3.5 \mu \mathrm{m}, 4.6 \times 100 \mathrm{~mm})$ (Agilent Technologies). Flow rate: $0.5 \mathrm{~mL} / \mathrm{min}$. Column temperature: $20{ }^{\circ} \mathrm{C}$. Detection wavelength: $365 \mathrm{~nm}$. HPLC gradient: $20-80 \%$ B in $8 \mathrm{~min}, 80-20 \% \mathrm{~B}$ in $4 \mathrm{~min}$, then held at $20 \% \mathrm{~B}$ for $3 \min (\mathrm{A}=$ water, $\mathrm{B}=$ acetonitrile $)$. 


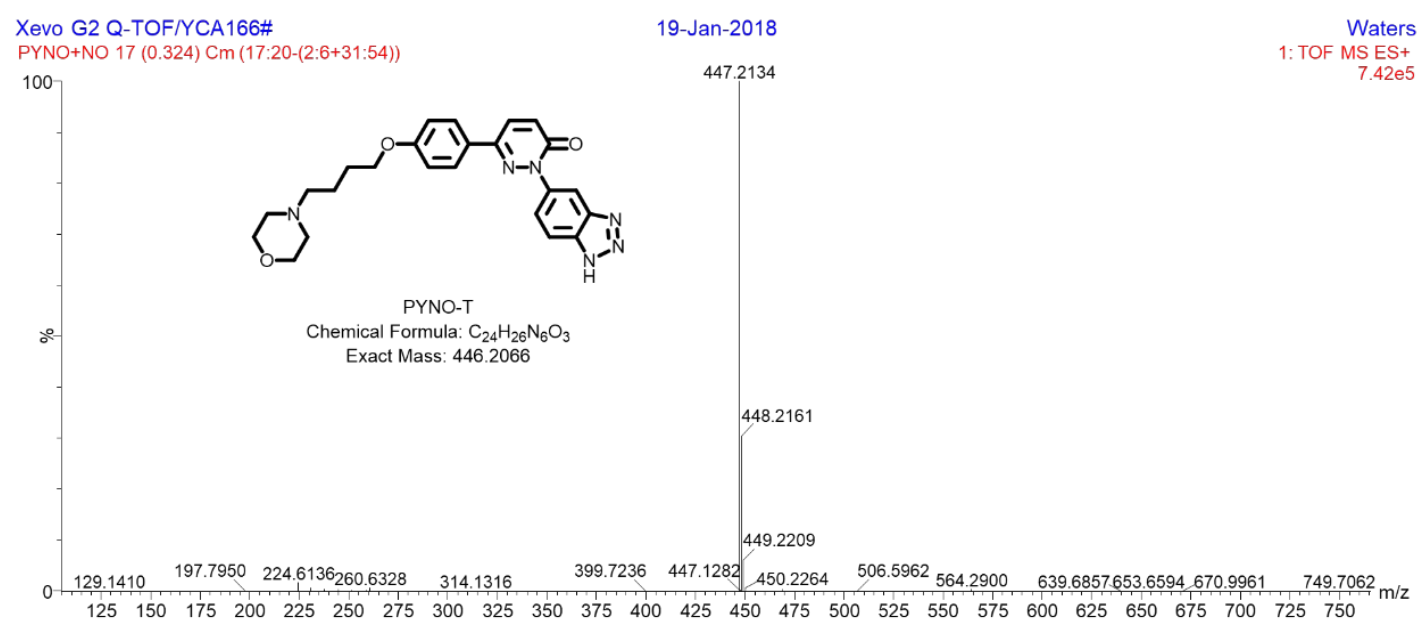

Figure S3. The HRMS spectrum of PYNO in the presence of excess NO showing a peak at $\mathrm{m} / \mathrm{z}$ 447.2134, corresponding to the expected triazole product PYNO-T $([\mathrm{M}+\mathrm{H}]+, \mathrm{m} / \mathrm{z}$, calcd. 447.2145).

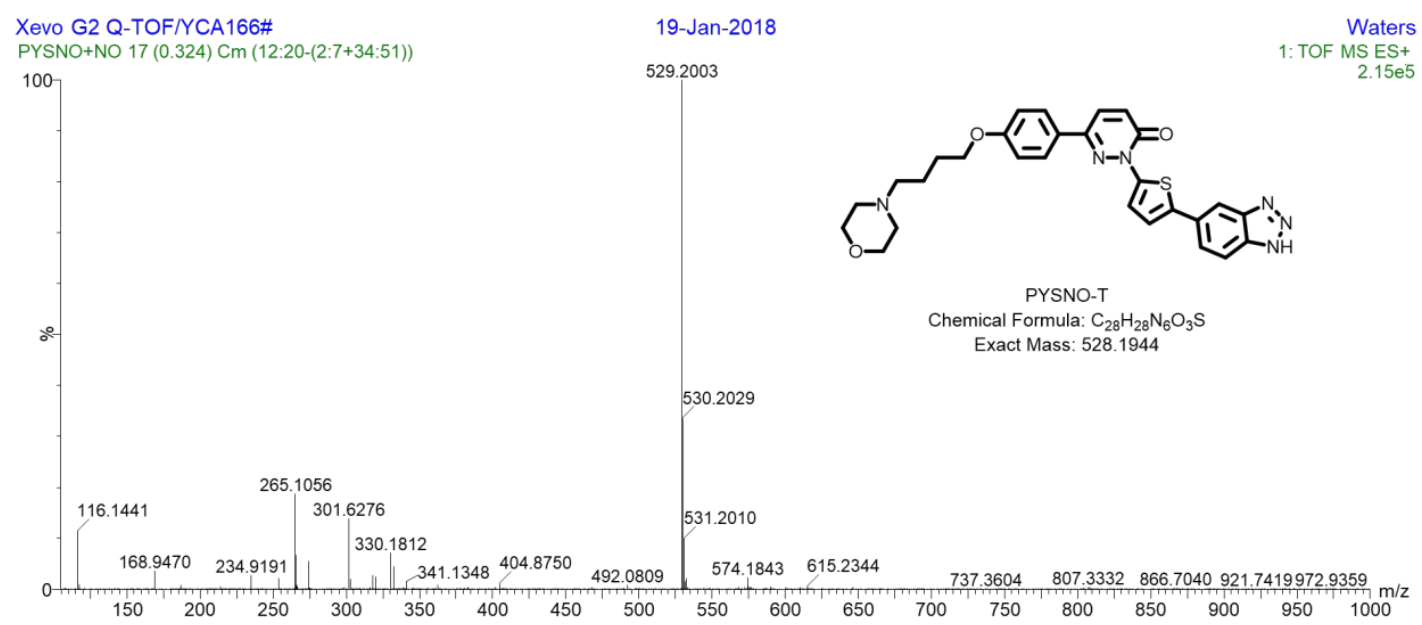

Figure S4. The HRMS (ESI) spectrum of PYSNO after bubbling excess NO showing a peak at $\mathrm{m} / \mathrm{z} 529.2003$ which is consistent with the expected triazole product PYSNO$\mathrm{T}([\mathrm{M}+\mathrm{H}]+, \mathrm{m} / \mathrm{z}$, calcd. 529.2022) 


\section{Biological assays of probes}

\section{Cytotoxicity assay}

The cytotoxicity assays were conducted according to the literature. ${ }^{6} \mathrm{SH}-\mathrm{SY} 5 \mathrm{Y}$ cells were seeded in flat-bottomed 96-well plates, 104 cells per well, with $200 \mu \mathrm{L}$ complete culture media in the dark for $24 \mathrm{~h}$. After washed with PBS for three times $\left(200 \mu \mathrm{L}^{*} 3\right)$, the cells were incubated with appropriate concentrations of probe. All stock solutions were prepared in DMSO and diluted with complete media, and the final DMSO concentrations were less than $0.1 \%$. After cultured for $24 \mathrm{~h}$, the cells were washed with PBS three times $\left(200 \mu \mathrm{L}^{*} 3\right) .10 \mu \mathrm{L}$ Cell Counting Kit-8 (CCK-8) solution and $90 \mu \mathrm{L}$ PBS were added per well simultaneously. After 2 hours, the absorbance at $450 \mathrm{~nm}$ was read by $96-$ well plate reader. The viability of SH-SY5Y cells was calculated by the following equation:

$$
\mathrm{CV}=(\mathrm{As}-\mathrm{Ab}) /(\mathrm{Ac}-\mathrm{Ab}) \times 100 \%
$$

where CV stands for the viability of cells, As, Ac and Ab stand for the absorbance of cells containing probe, cell control ( $0 \mu \mathrm{M}$ probe) and blank control (wells containing no cells or probe) 


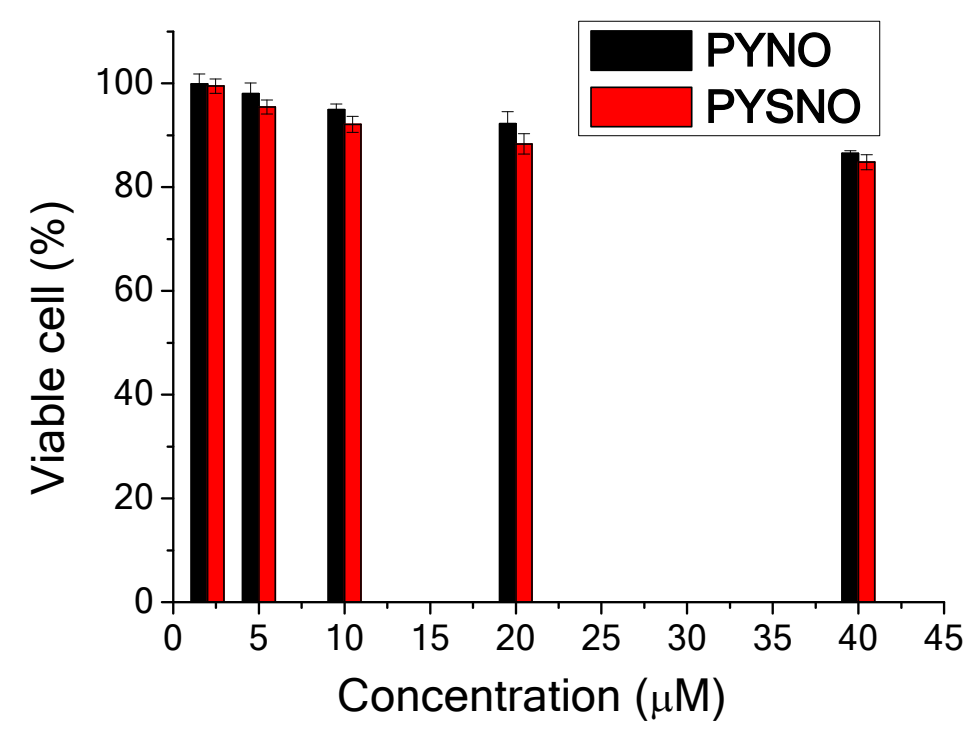

Figure S5. CCK-8 assay result of PYNO and PYSNO. Cells were incubated with different concentrations of PYNO/PYSNO under dark.

Colocalization imaging of probe PYNO
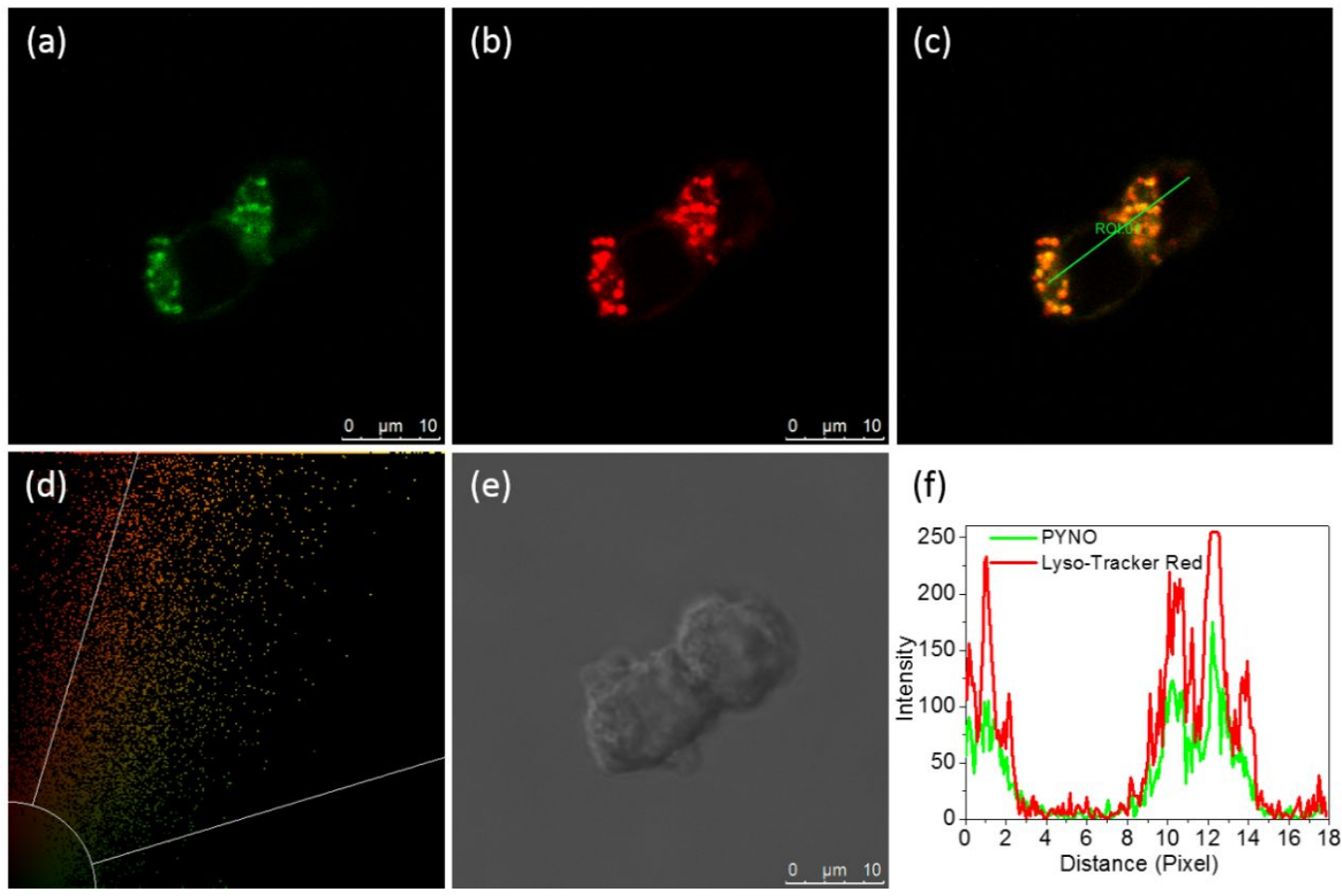

(e)

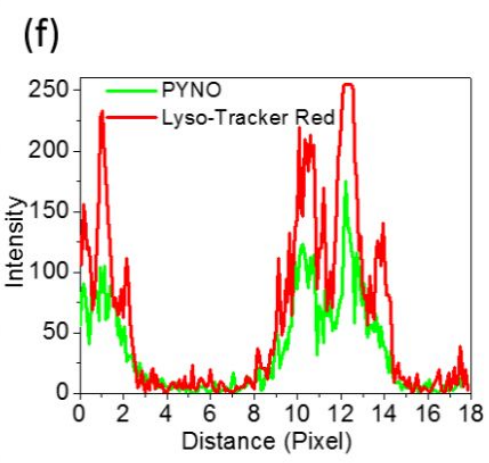

Figure S6. Colocalization images of PYNO with Lyso-Tracker Red in SH-SY5Y cells. SH-SY5Y cells were incubated with $5 \mu \mathrm{M}$ PYNO and 100 nM Lyso-Tracker Red for 
$30 \mathrm{~min}$ and then 10 equiv. of NO for $30 \mathrm{~min}$. Fluorescence collection windows for the green channel (a) $435-585 \mathrm{~nm}\left(\lambda_{\mathrm{ex}}=405 \mathrm{~nm}\right)$, red channel (b) $575-650 \mathrm{~nm}\left(\lambda_{\mathrm{ex}}=561\right.$ nm). (c) Overlay image of (a) and (b). (d) Intensity scatter plot of the green channel and the red channel. (e) Bright field of the SH-SY5Y cells. (f) Intensity profile of ROI 1 across SH-SY5Y cells.

\section{Exogenous NO imaging}

(a)

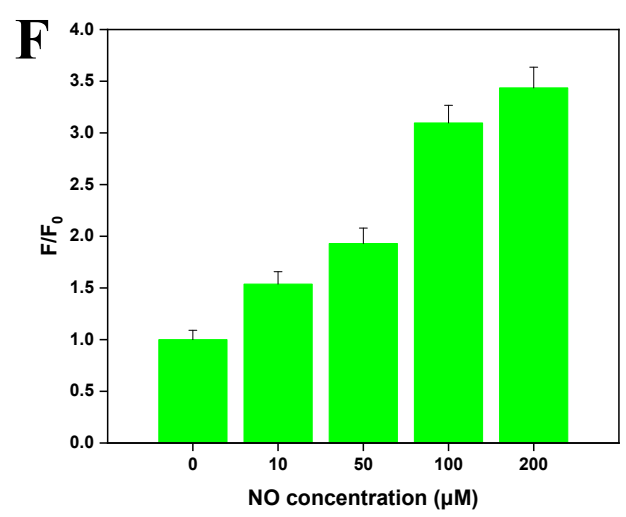

(b)

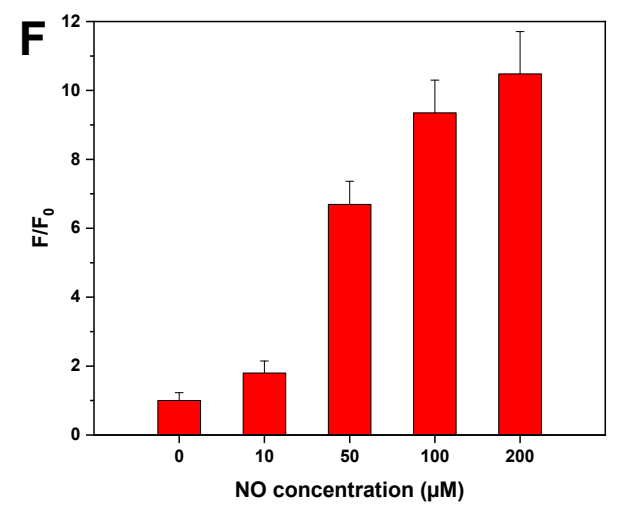

Figure S7. Relative enhancement of fluorescence intensity of (a) PYNO and (b) PYSNO by exogenous NO. 


\section{NMR and HRMS spectra}
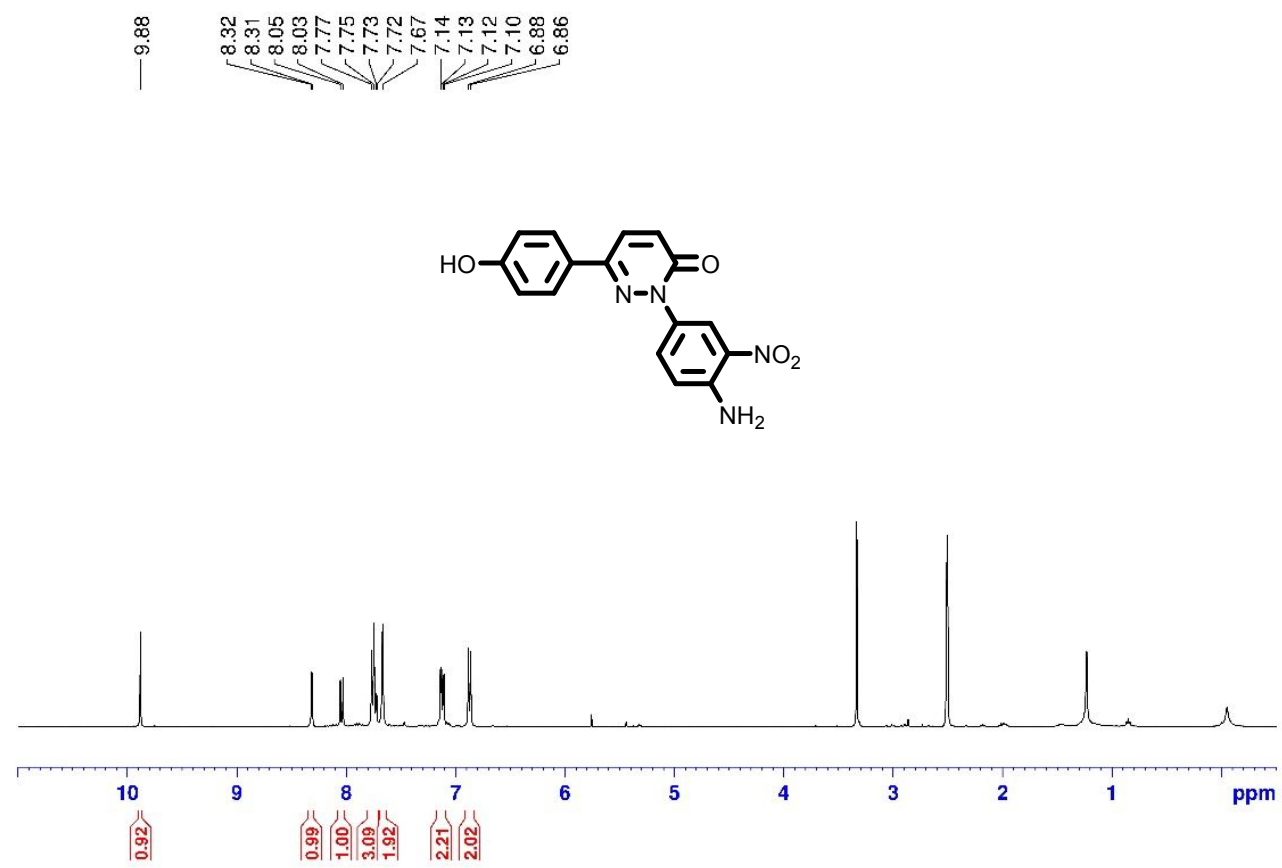

${ }^{1} \mathrm{H}$ NMR spectrum of compund 2 in DMSO- $d_{6}$

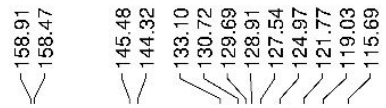

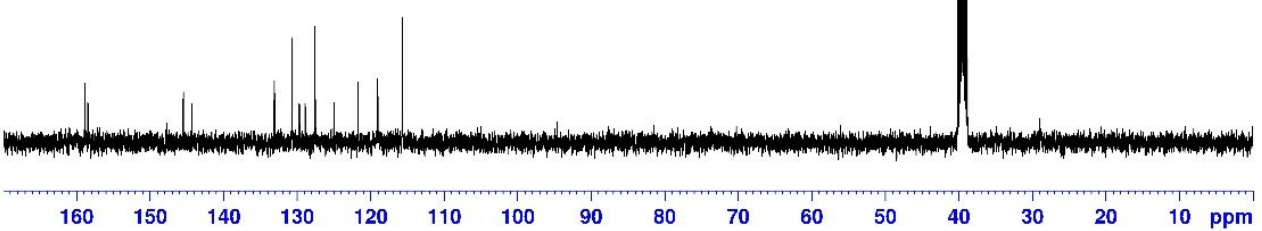

${ }^{13} \mathrm{C}$ NMR spectrum of compund 2 in DMSO- $d_{6}$ 


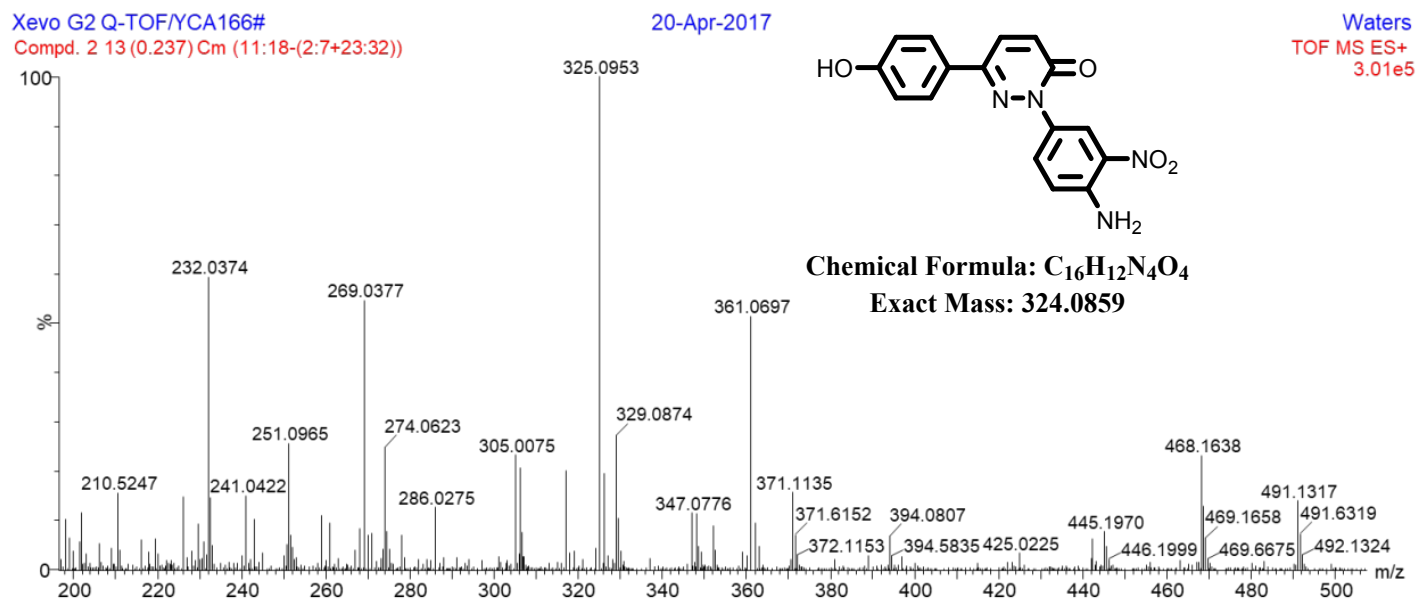

HRMS spectrum of compund 2 


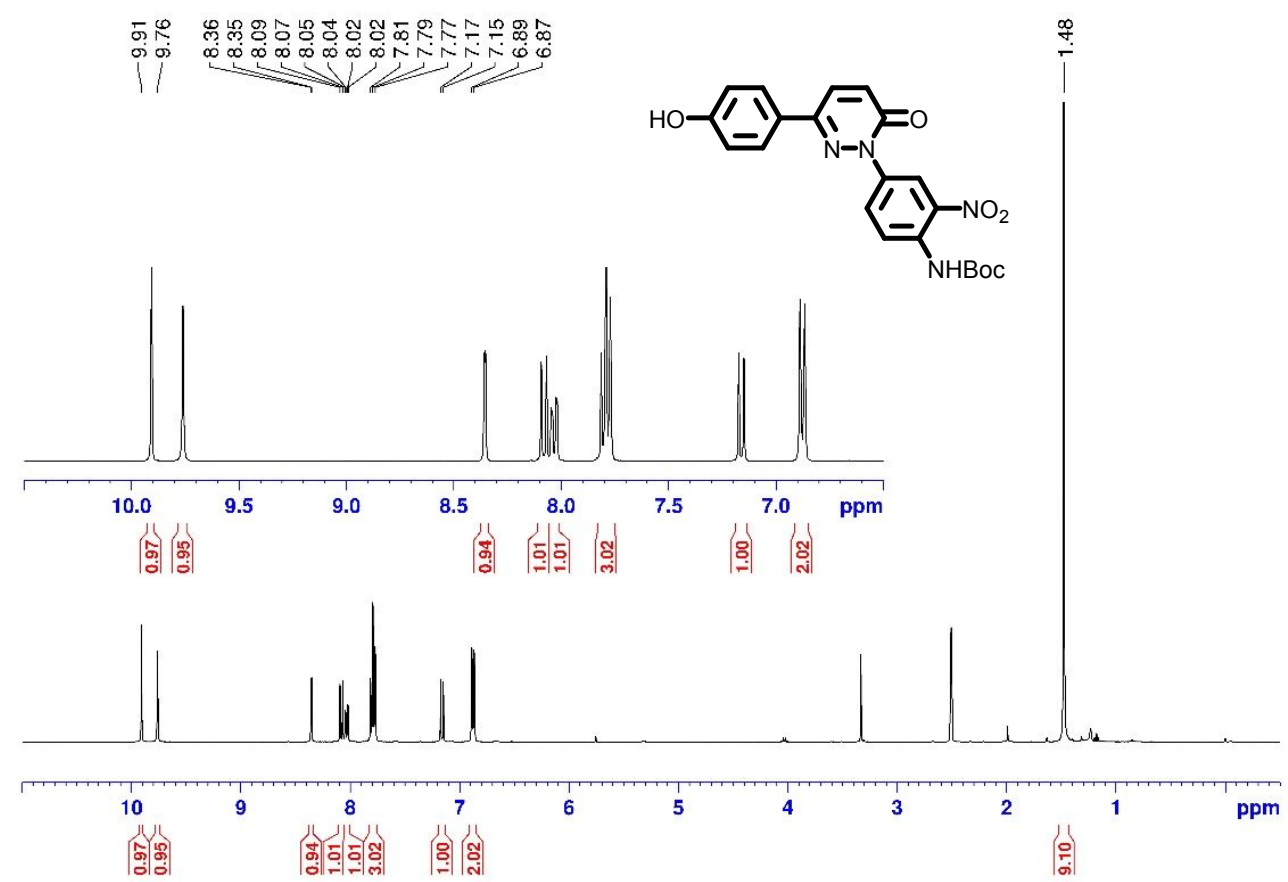

${ }^{1} \mathrm{H}$ NMR spectrum of compund 3 in DMSO- $d_{6}$

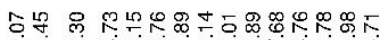

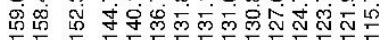

रं i
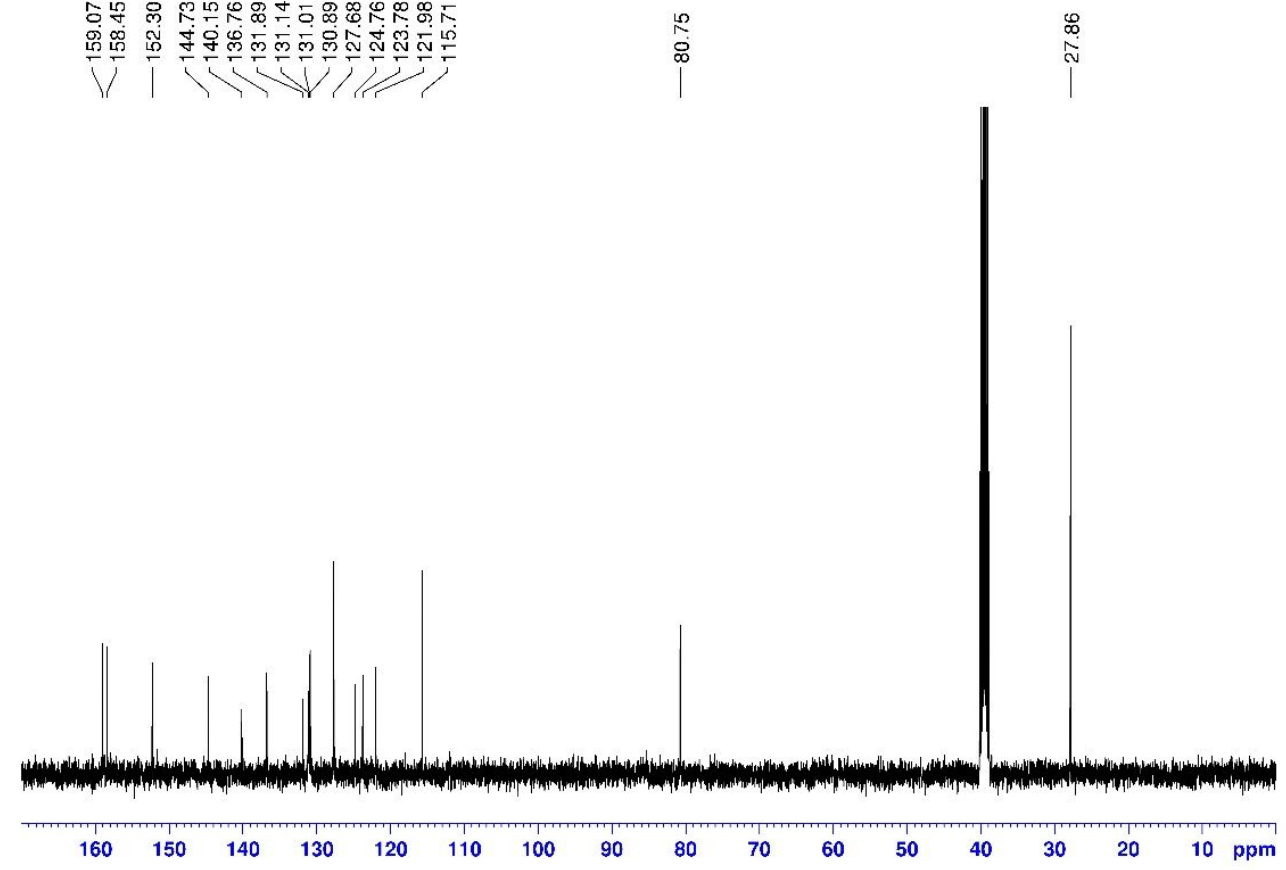

${ }^{13} \mathrm{C}$ NMR spectrum of compund 3 in DMSO- $d_{6}$ 


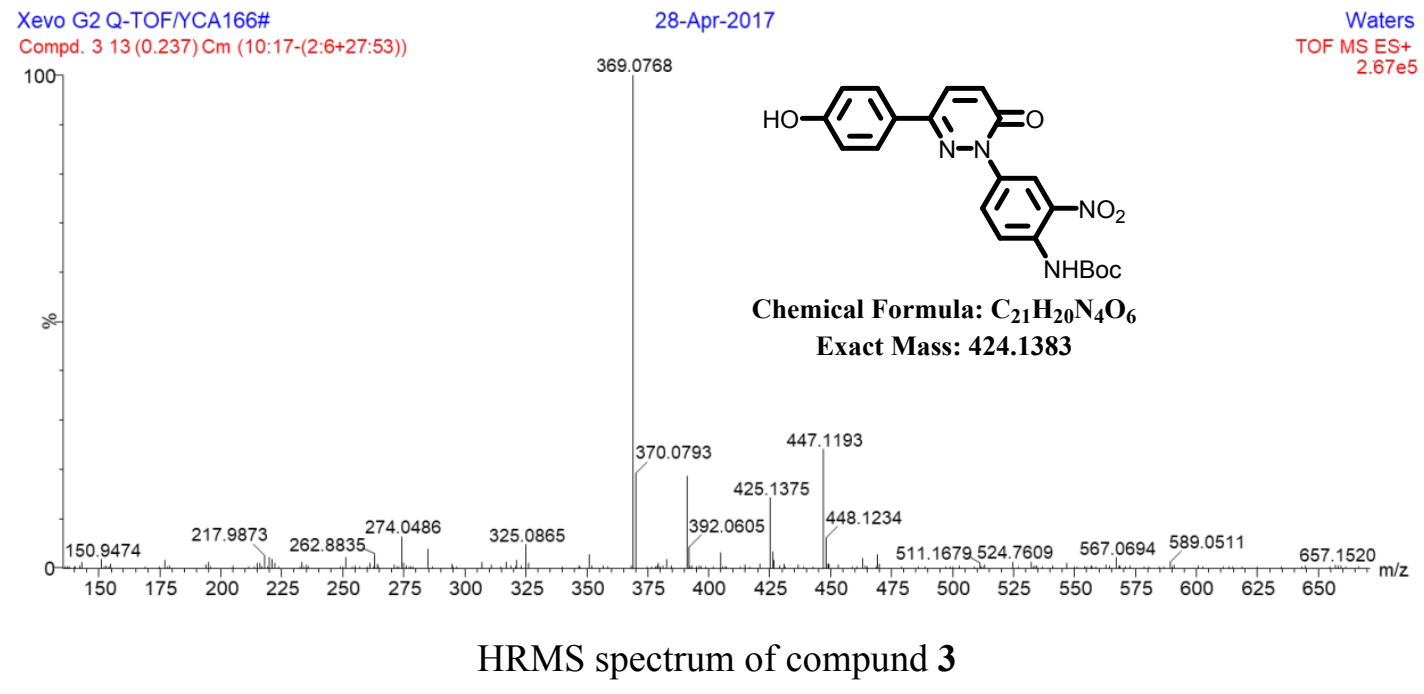




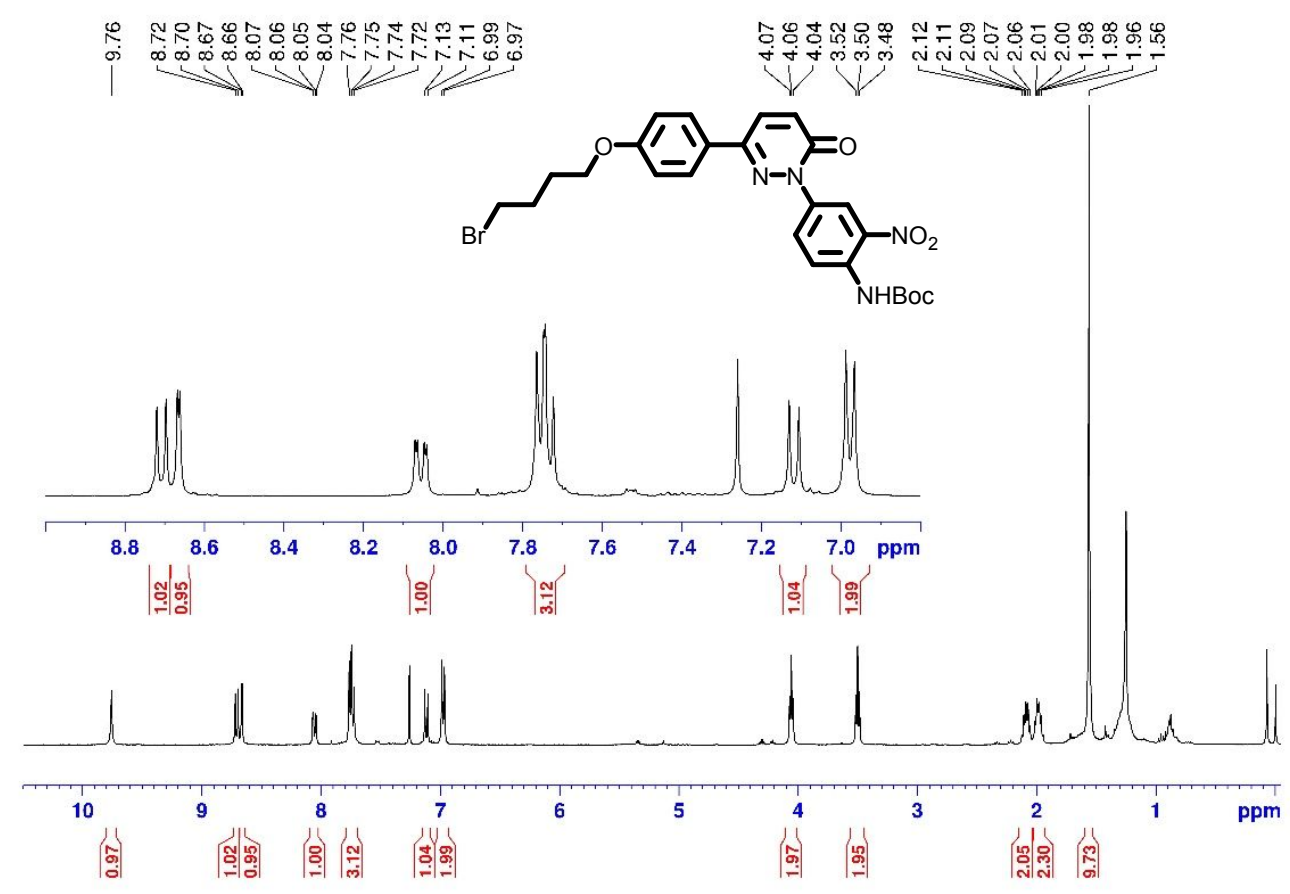

${ }^{1} \mathrm{H}$ NMR spectrum of compund 4 in $\mathrm{CDCl}_{3}$

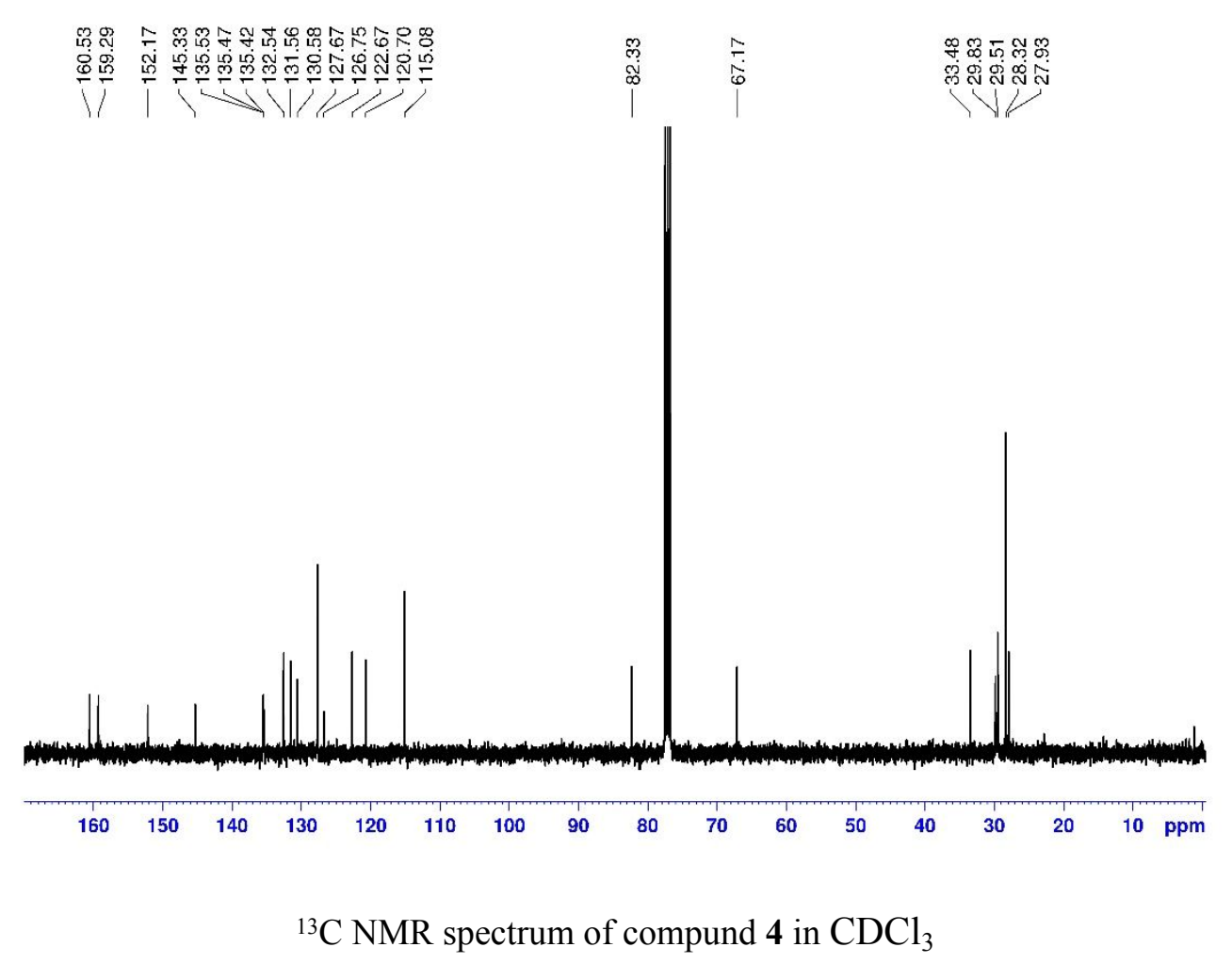




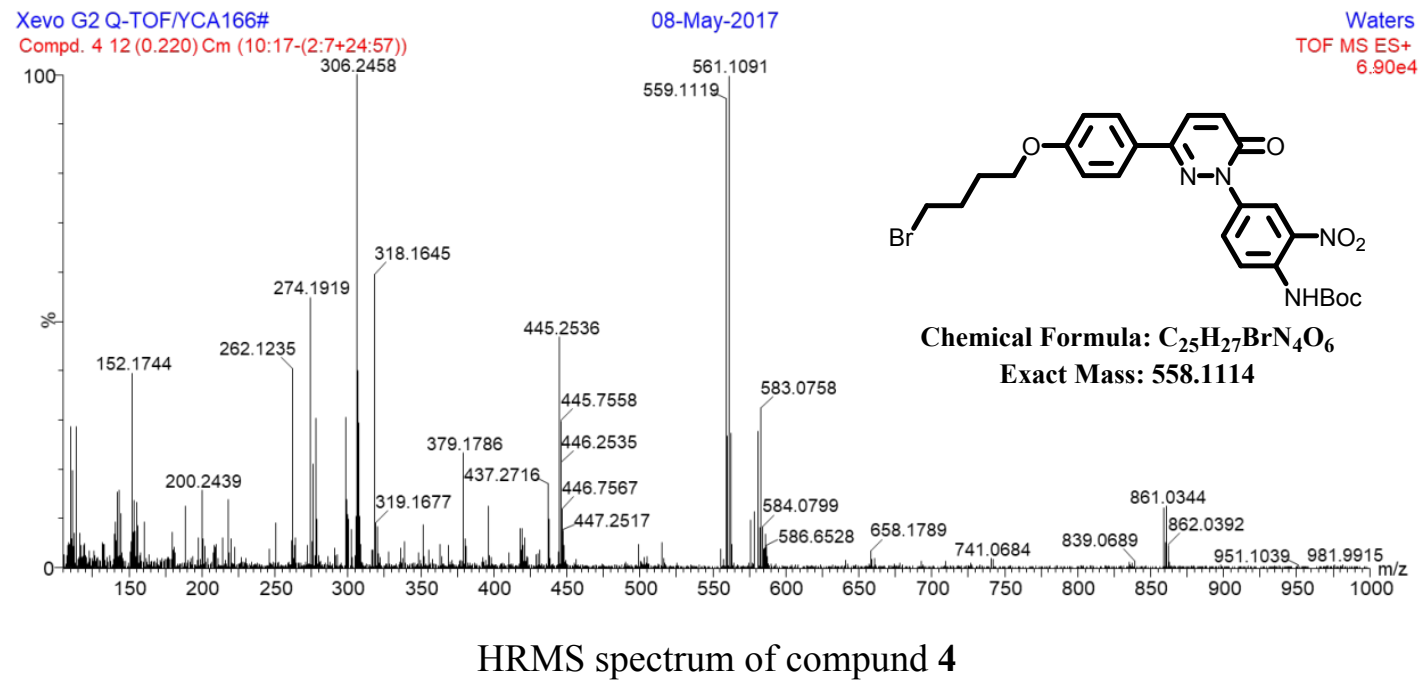




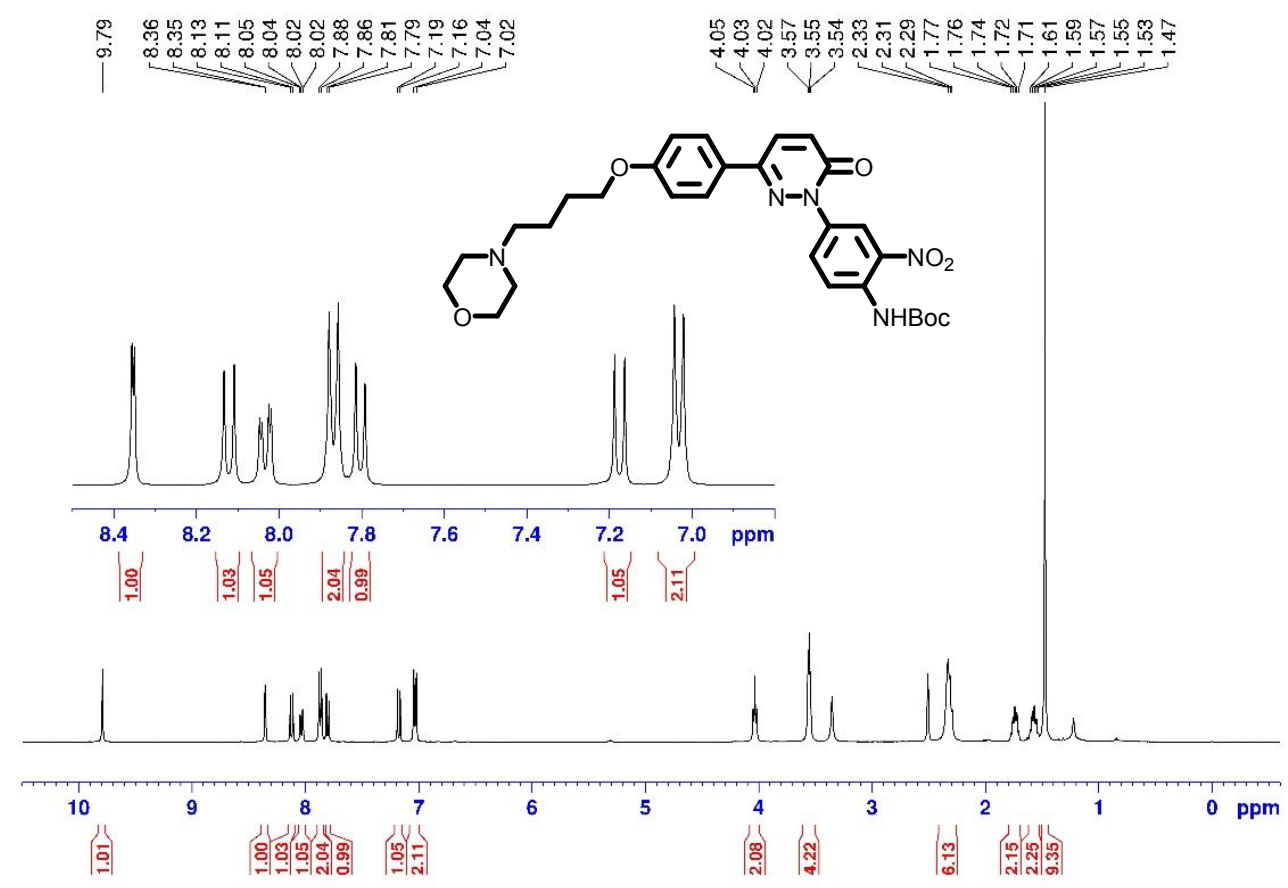

${ }^{1} \mathrm{H}$ NMR spectrum of compund 5 in DMSO- $d_{6}$

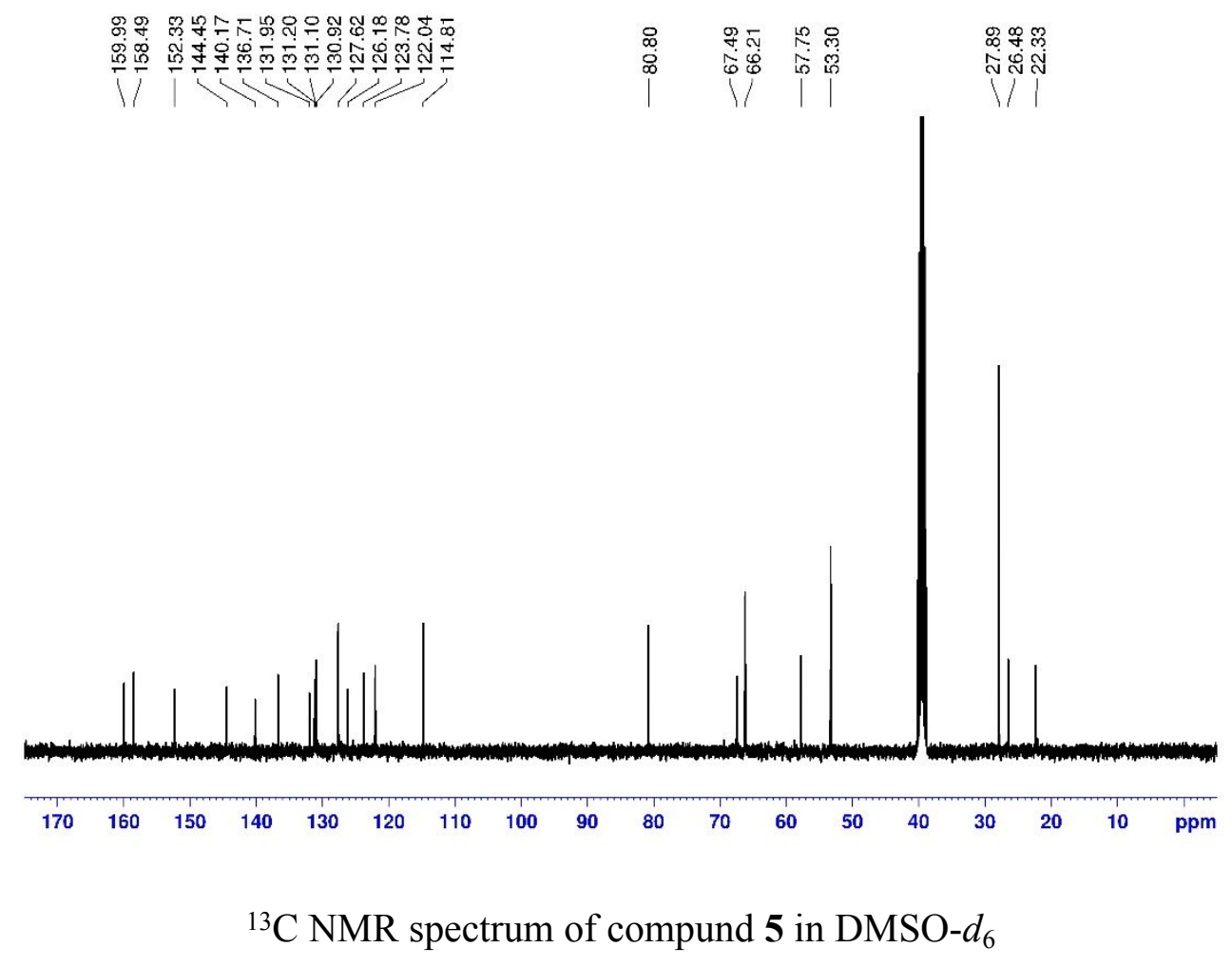




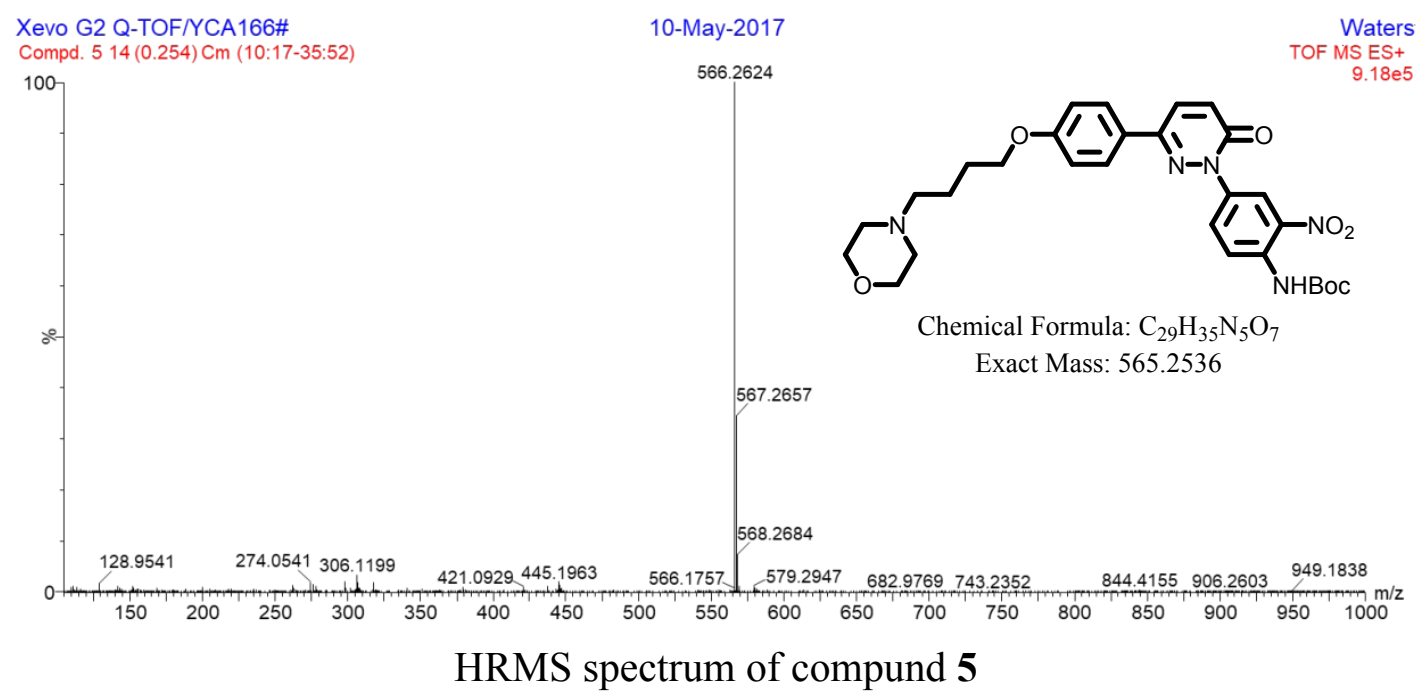




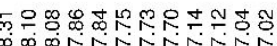

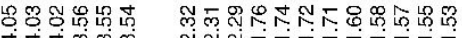

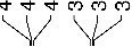

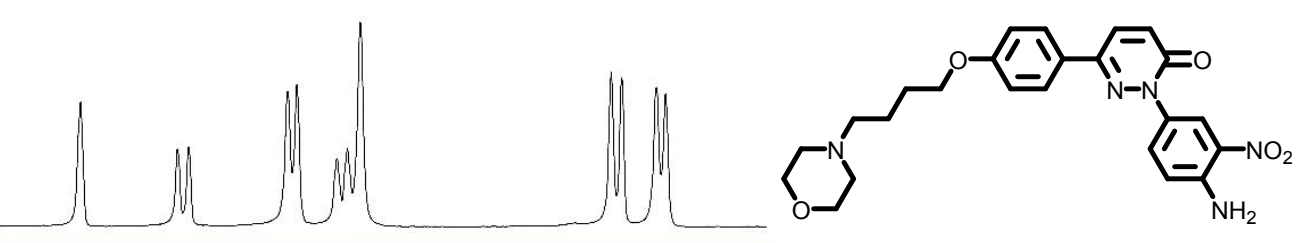

$\begin{array}{llllllllllllllll}8.4 & 8.3 & 8.2 & 8.1 & 8.0 & 7.9 & 7.8 & 7.7 & 7.6 & 7.5 & 7.4 & 7.3 & 7.2 & 7.1 & 7.0 & \mathrm{ppm}\end{array}$

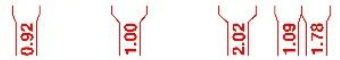

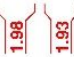

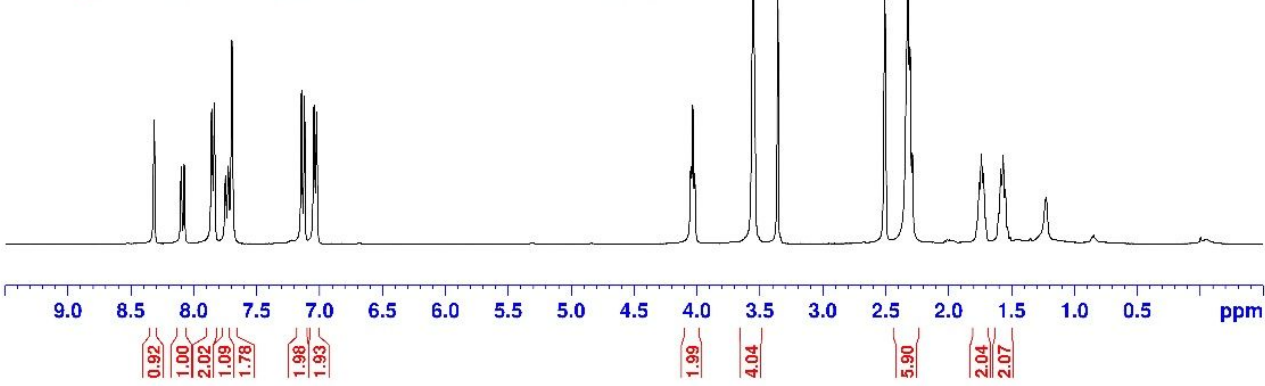

${ }^{1} \mathrm{H}$ NMR spectrum of compund 6 in DMSO- $d_{6}$
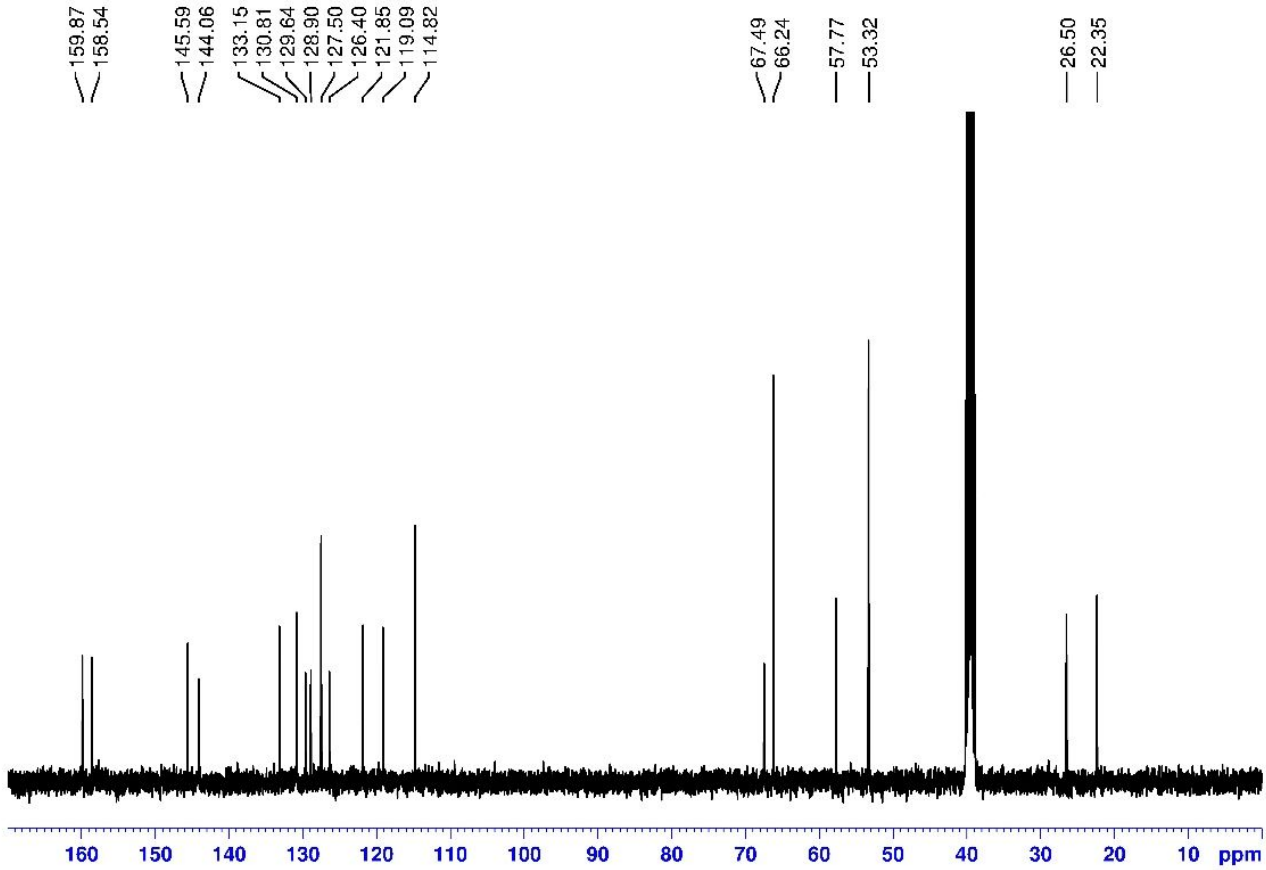

${ }^{13} \mathrm{C}$ NMR spectrum of compund 6 in DMSO- $d_{6}$ 


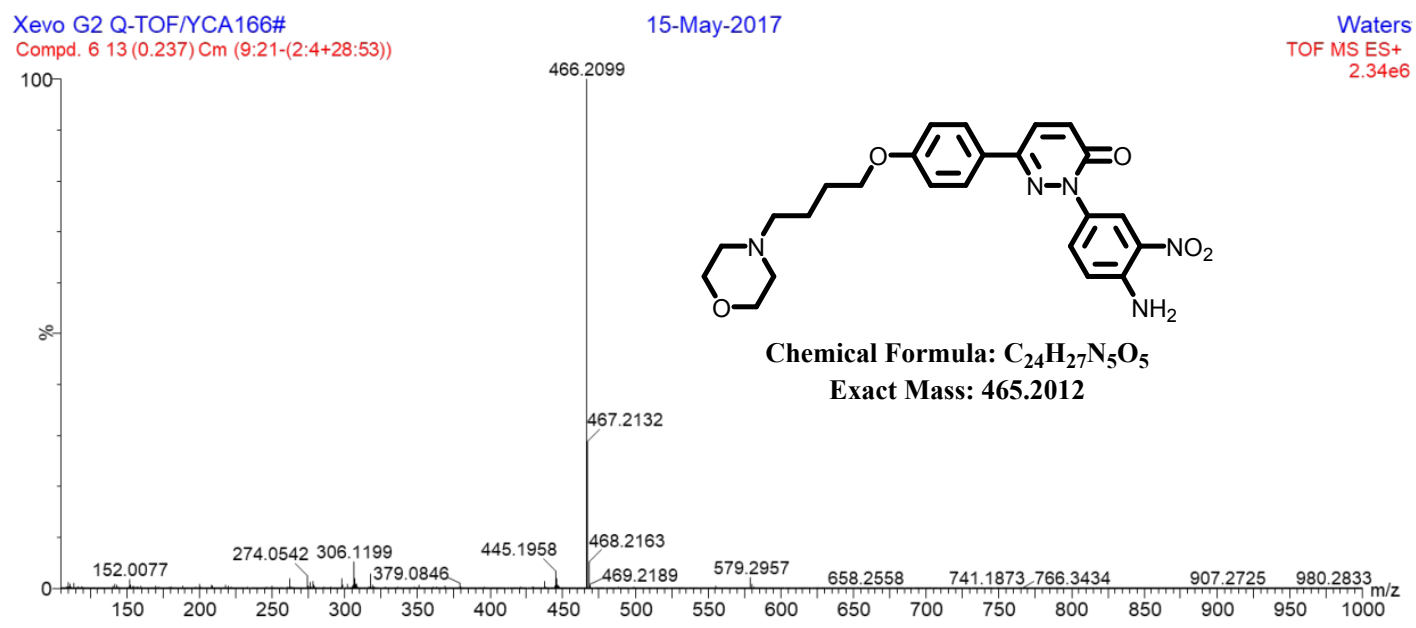

HRMS spectrum of compund 6 


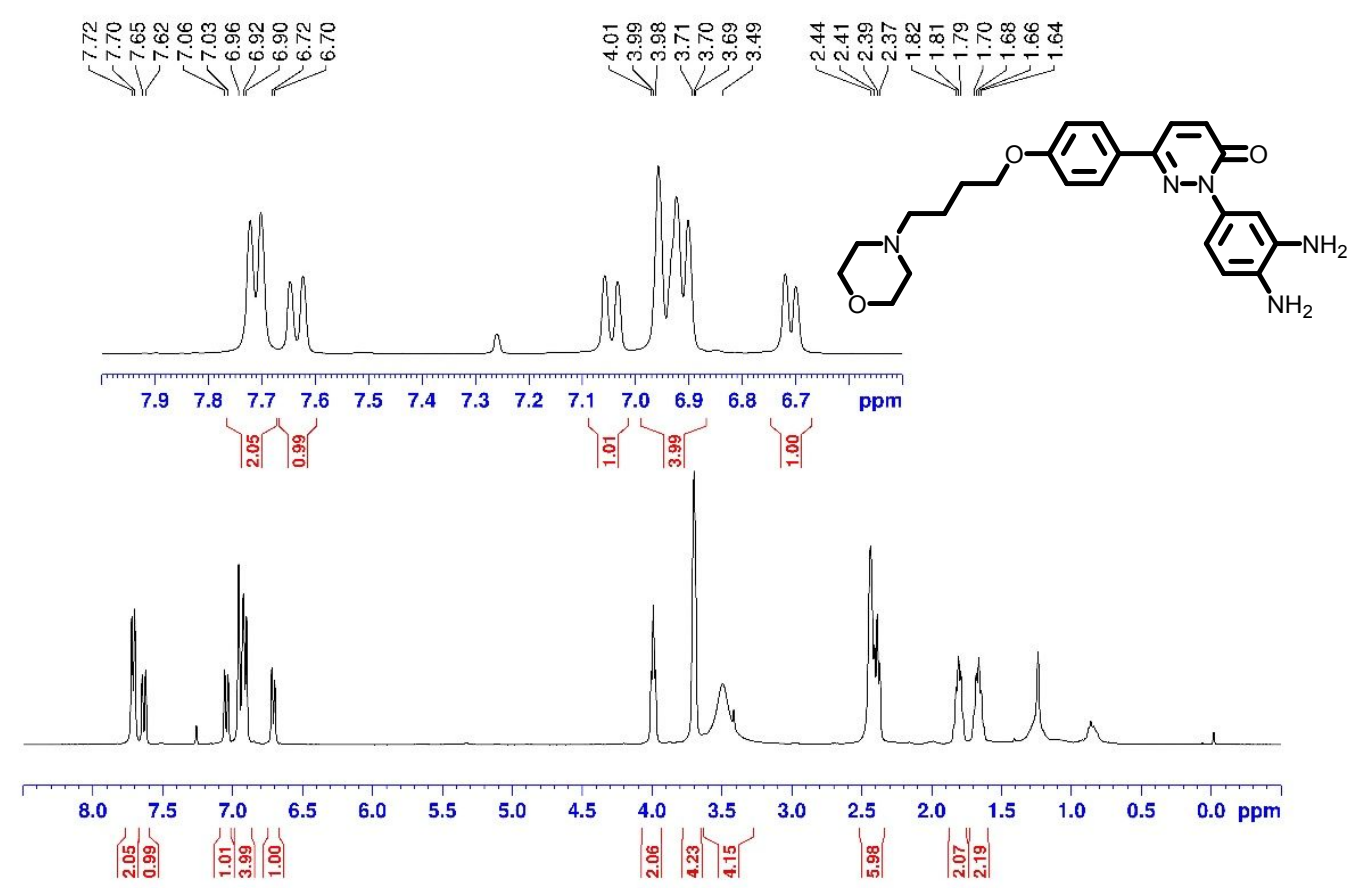

${ }^{1} \mathrm{H}$ NMR spectrum of PYNO in $\mathrm{CDCl}_{3}$

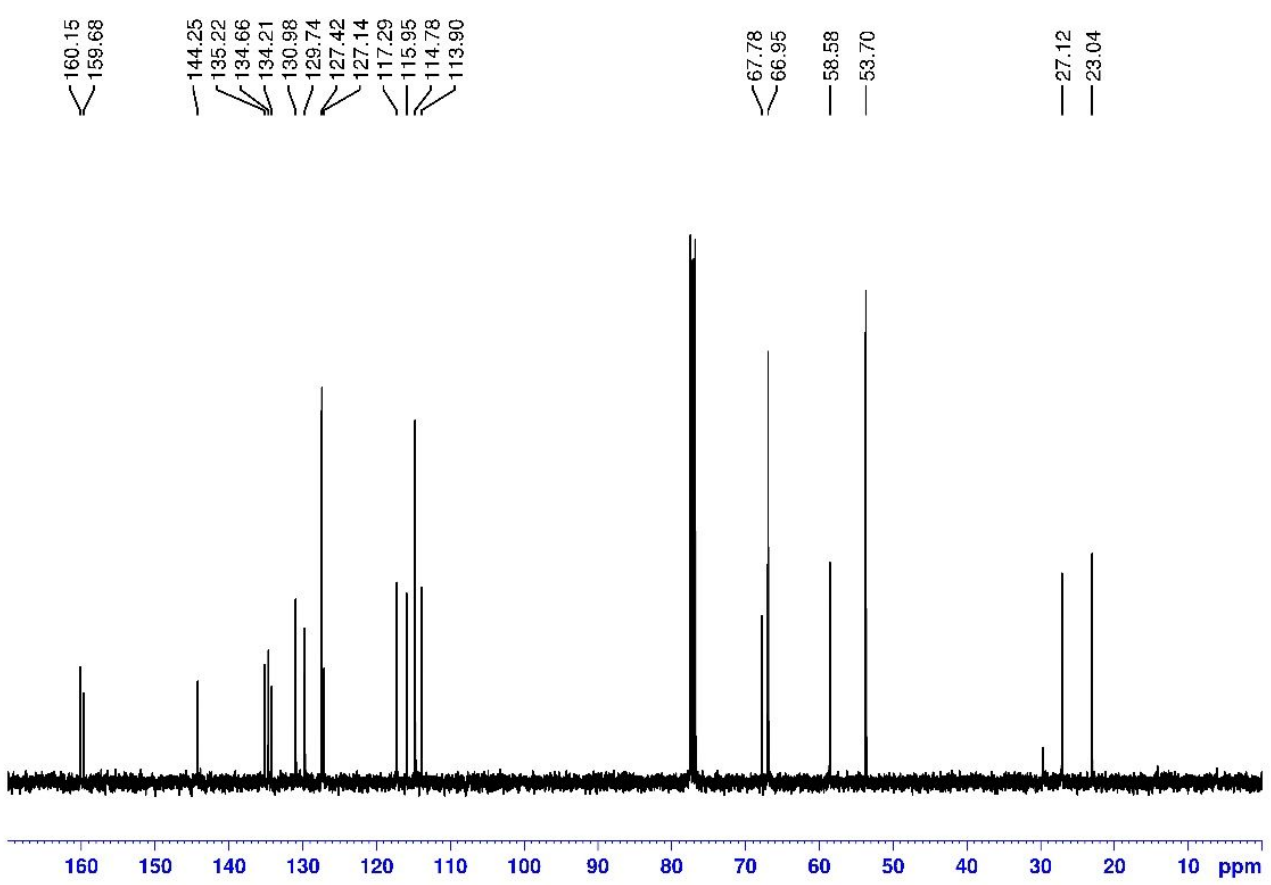

${ }^{13} \mathrm{C}$ NMR spectrum of PYNO in $\mathrm{CDCl}_{3}$ 
Xevo G2 Q-TOF/YCA166\#

Compd. PYNO $13(0.250) \mathrm{Cm}(11: 20-2: 8)$

100

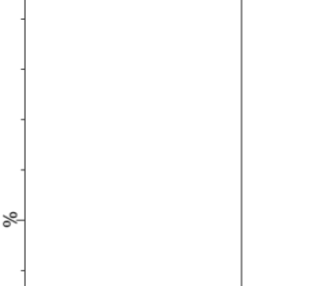

219.1230

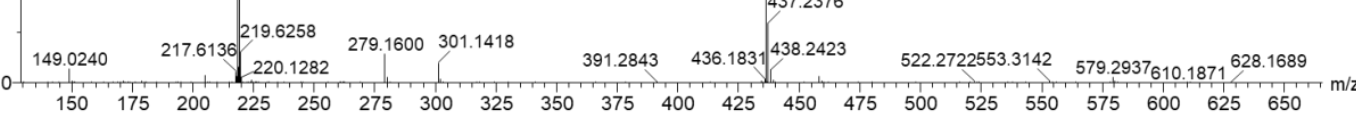

HRMS spectrum of PYNO 


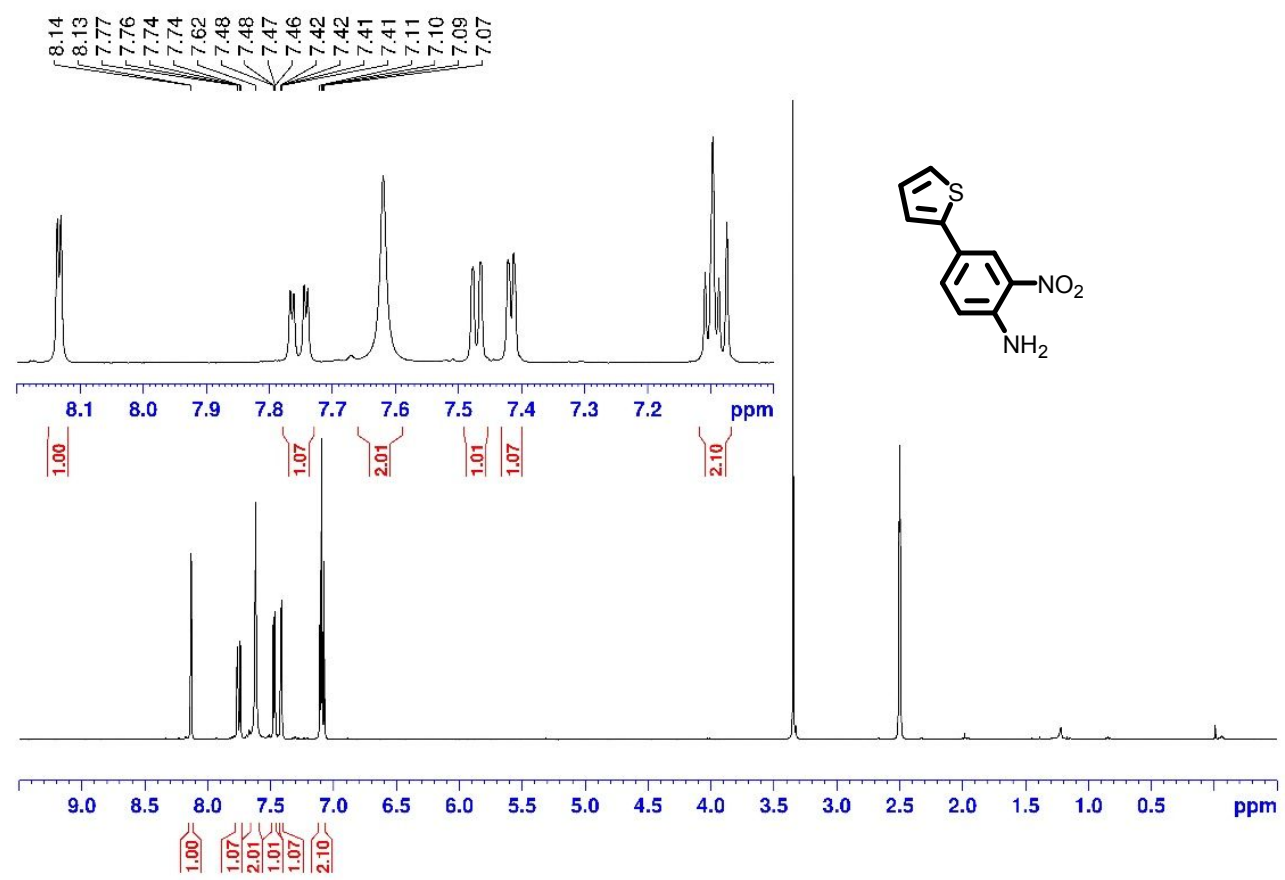

${ }^{1} \mathrm{H}$ NMR spectrum of compund 8 in DMSO- $d_{6}$

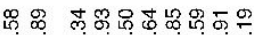

岁安

$11111 / 1$

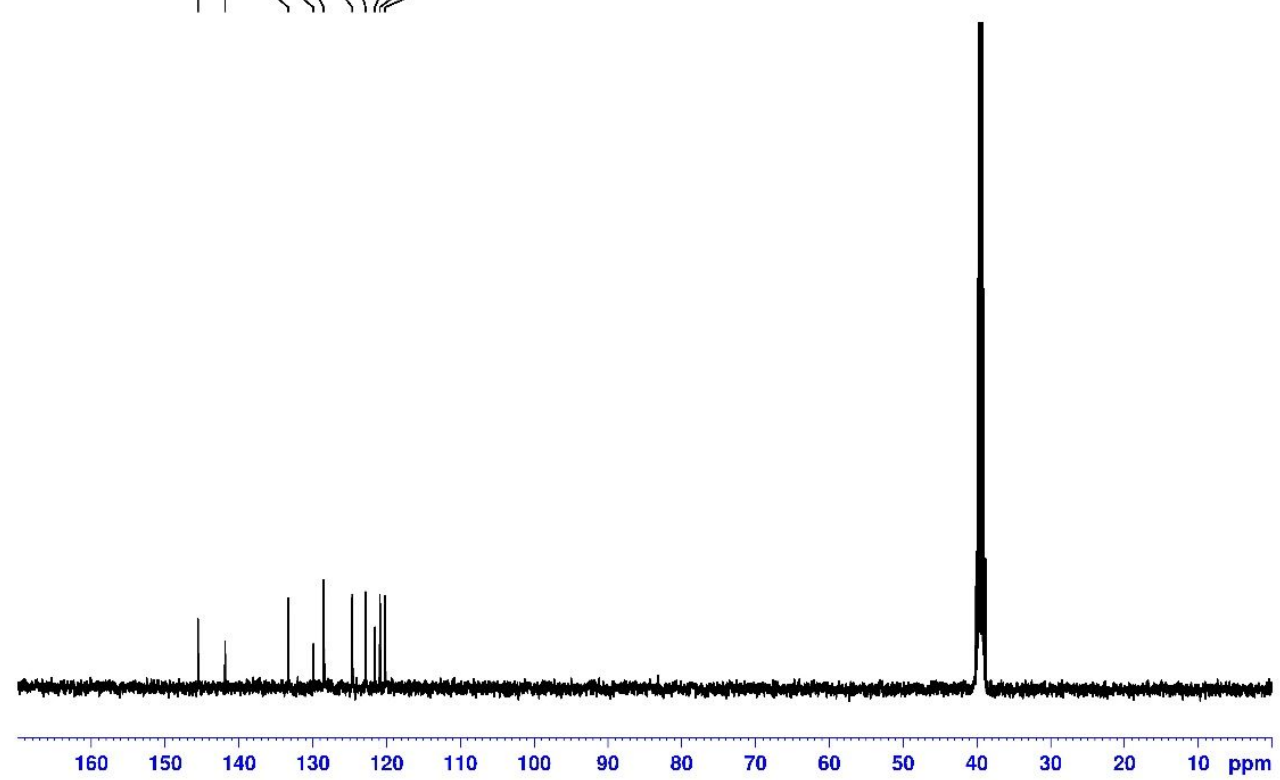

${ }^{13} \mathrm{C}$ NMR spectrum of compund 8 in DMSO- $d_{6}$ 
Xevo G2 Q-TOF/YCA166\#

Compd. 8 NEG-0629 $10(0.186)$ Cm (10:16-(2:6+24:57))
219.0229

100

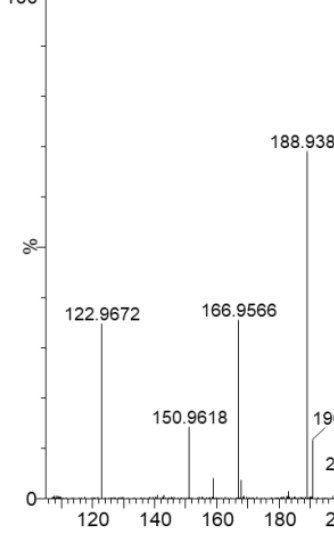

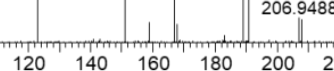

29-Jun-2017

Waters

TOF MS ES-

\section{HRMS spectrum of compund $\mathbf{8}$}




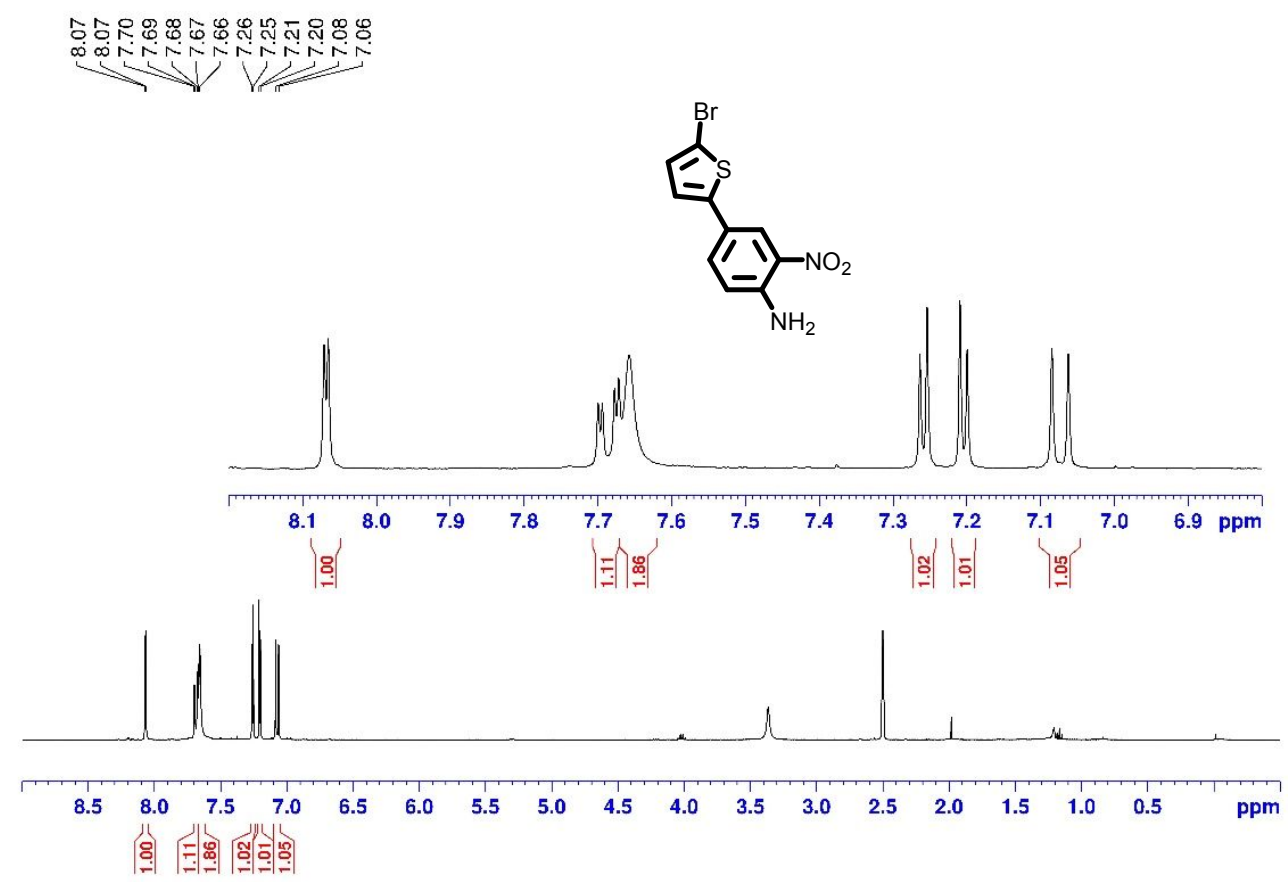

${ }^{1} \mathrm{H}$ NMR spectrum of compund 9 in DMSO- $d_{6}$

|ᄂ

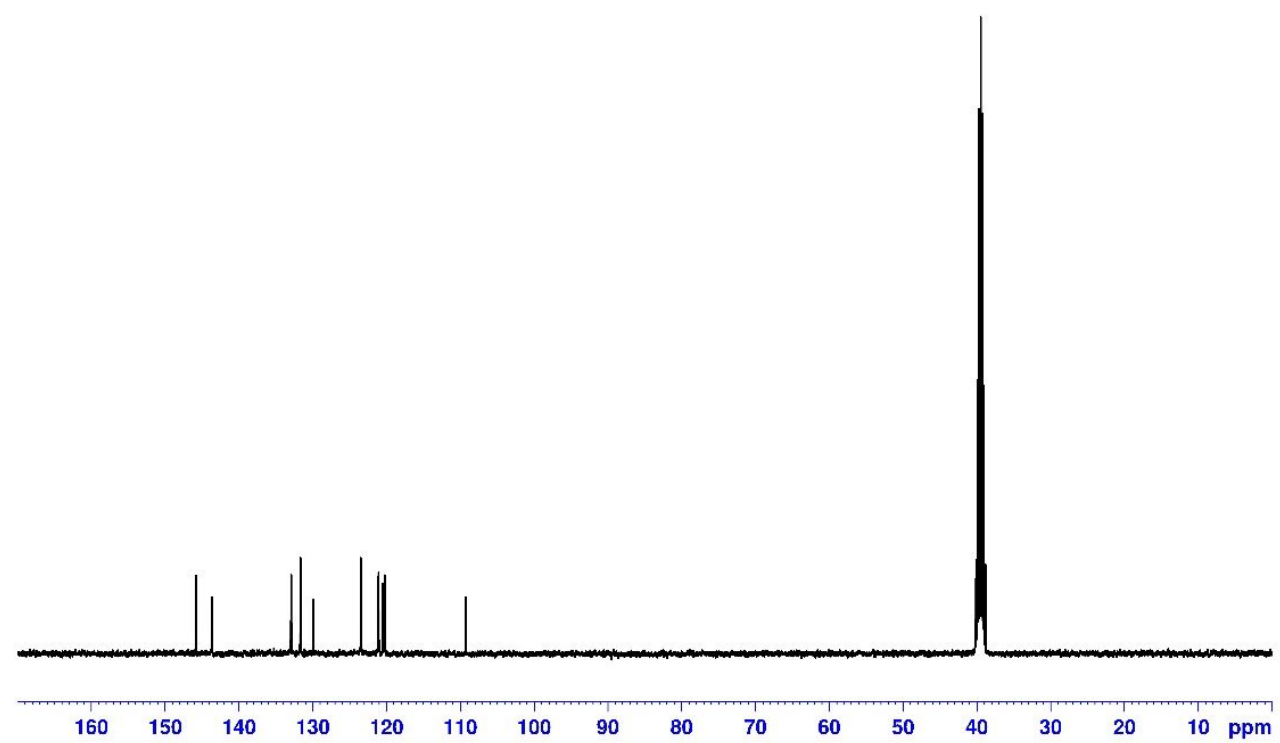

${ }^{13} \mathrm{C}$ NMR spectrum of compund 9 in DMSO- $d_{6}$ 


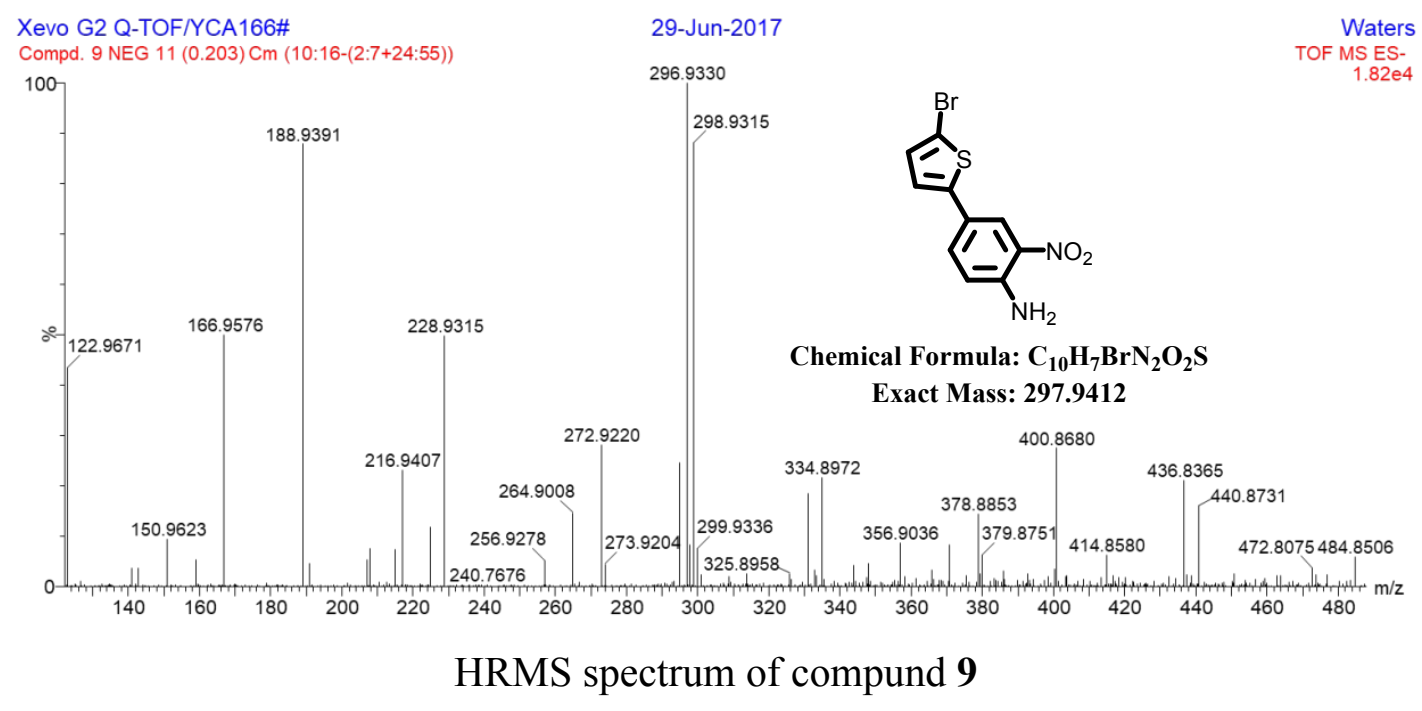




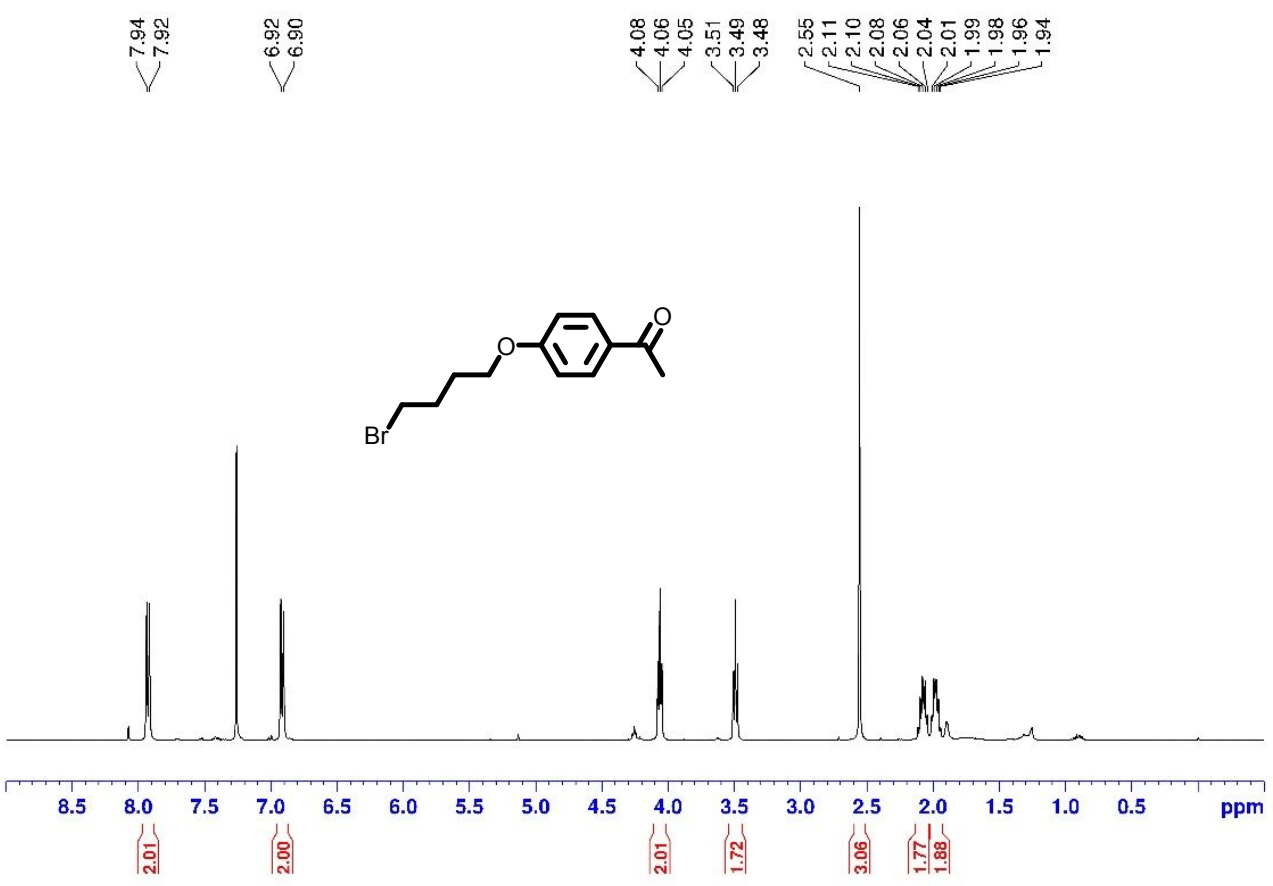

${ }^{1} \mathrm{H}$ NMR spectrum of compund $\mathbf{1 0}$ in $\mathrm{CDCl}_{3}$

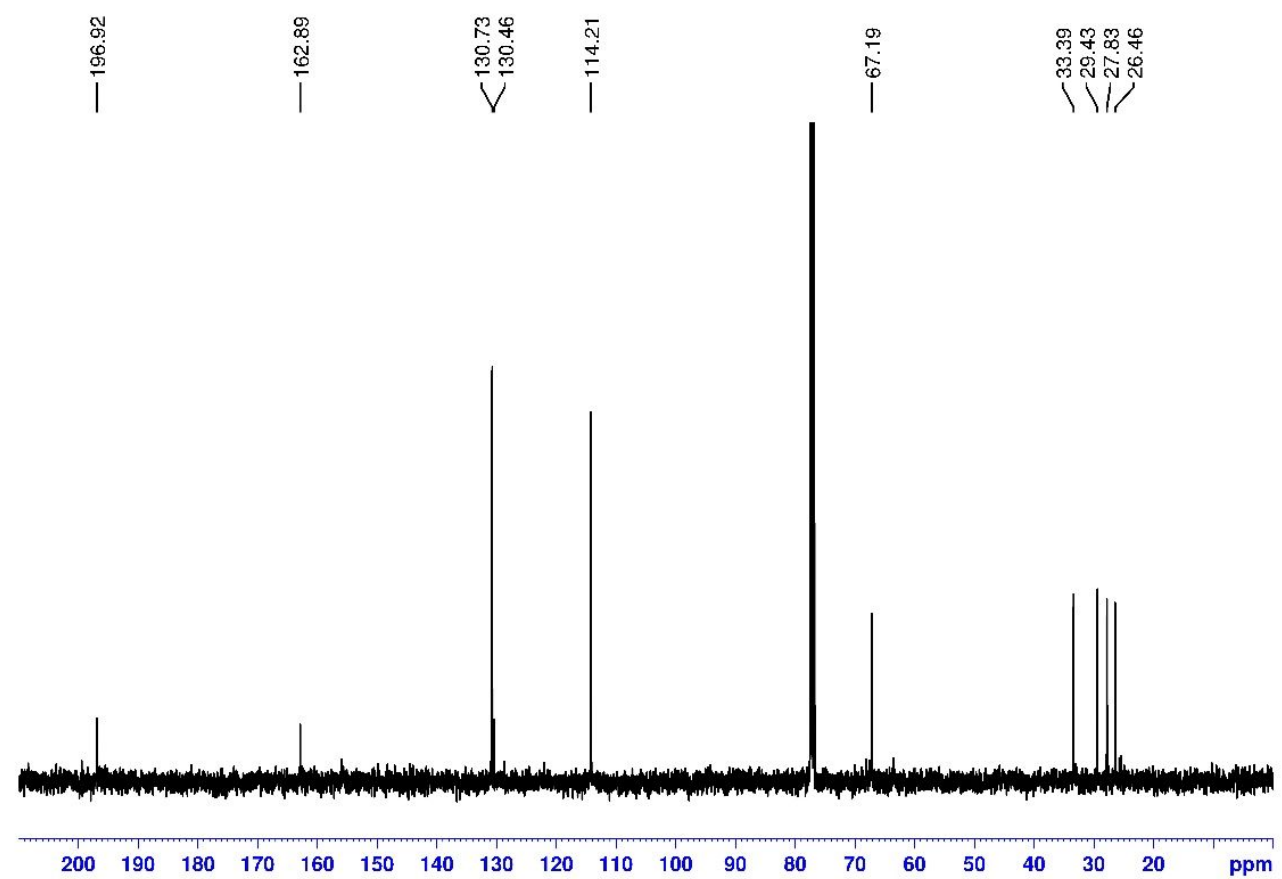

${ }^{13} \mathrm{C}$ NMR spectrum of compund $\mathbf{1 0}$ in $\mathrm{CDCl}_{3}$ 


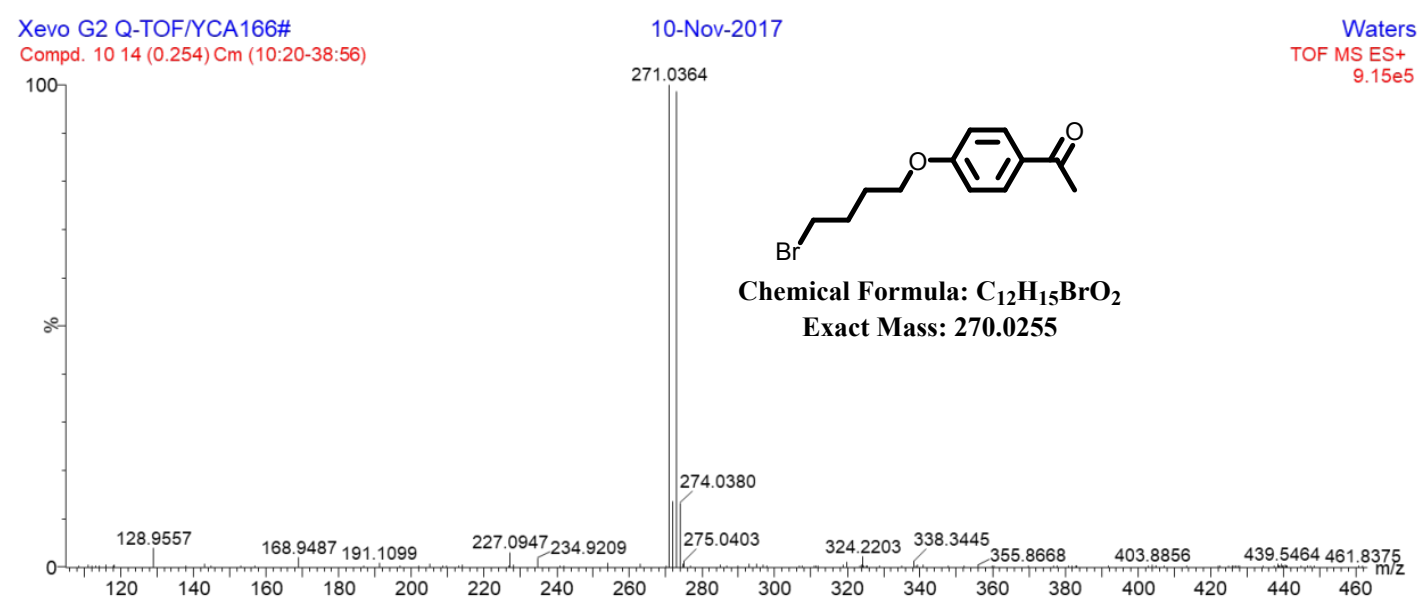

HRMS spectrum of compund $\mathbf{1 0}$ 


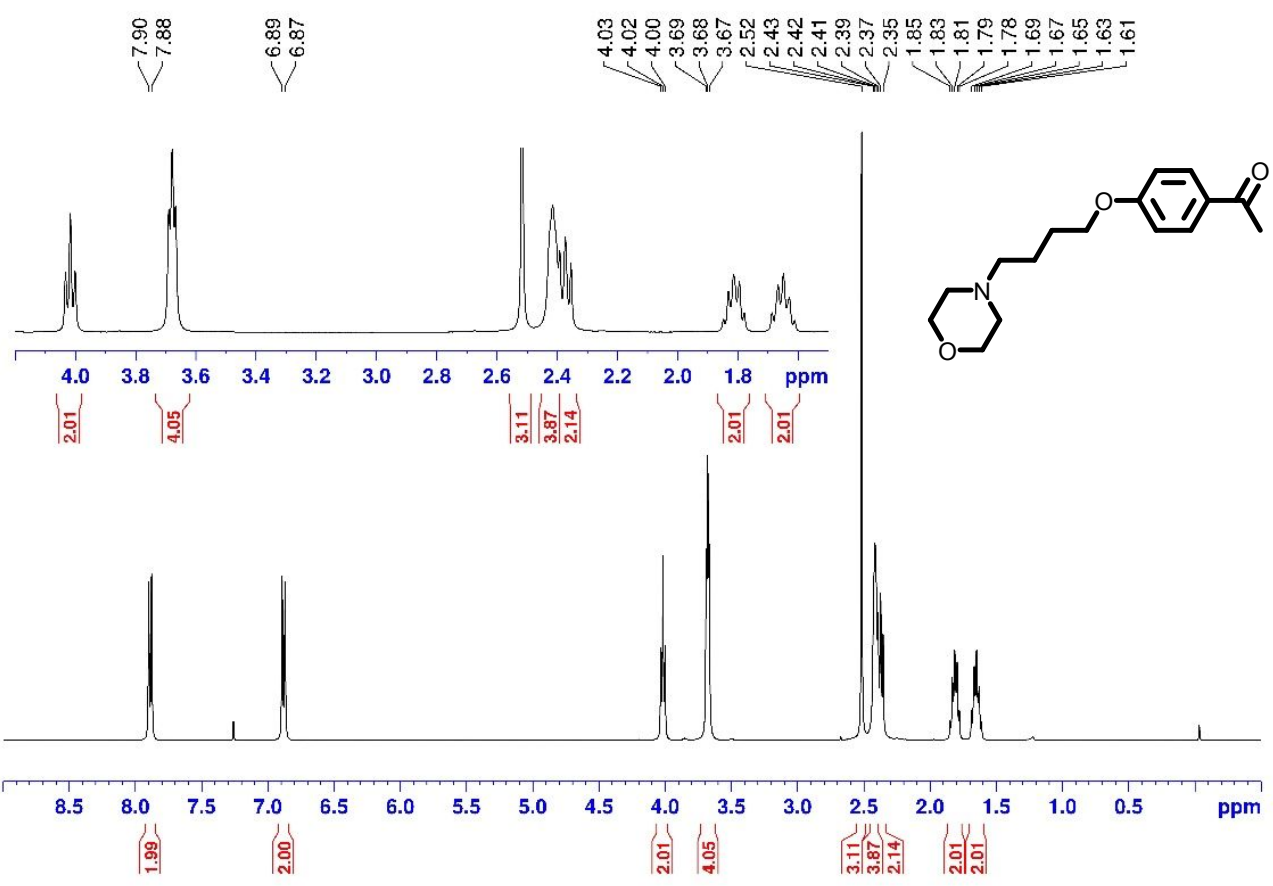

${ }^{1} \mathrm{H}$ NMR spectrum of compund 11 in $\mathrm{CDCl}_{3}$

$\underbrace{\substack{0 \\ 0}}_{\substack{\infty \\ 0}}$

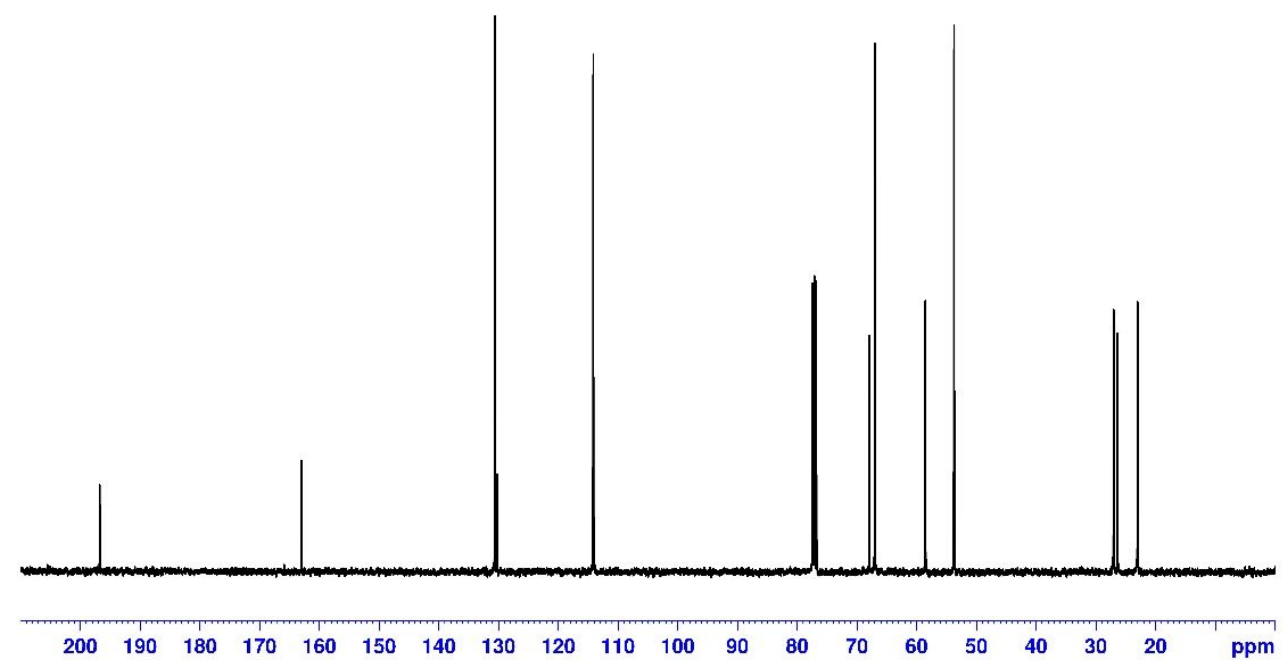

${ }^{13} \mathrm{C}$ NMR spectrum of compund 11 in $\mathrm{CDCl}_{3}$ 


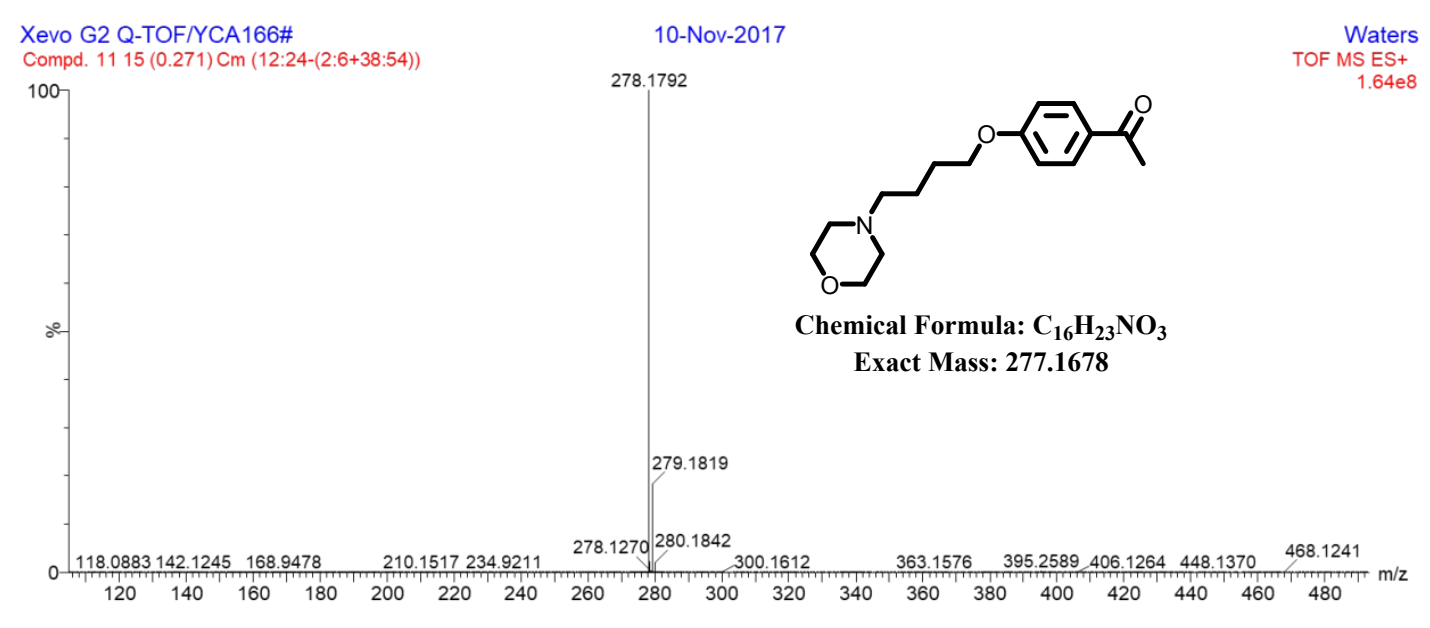

HRMS spectrum of compund $\mathbf{1 1}$ 


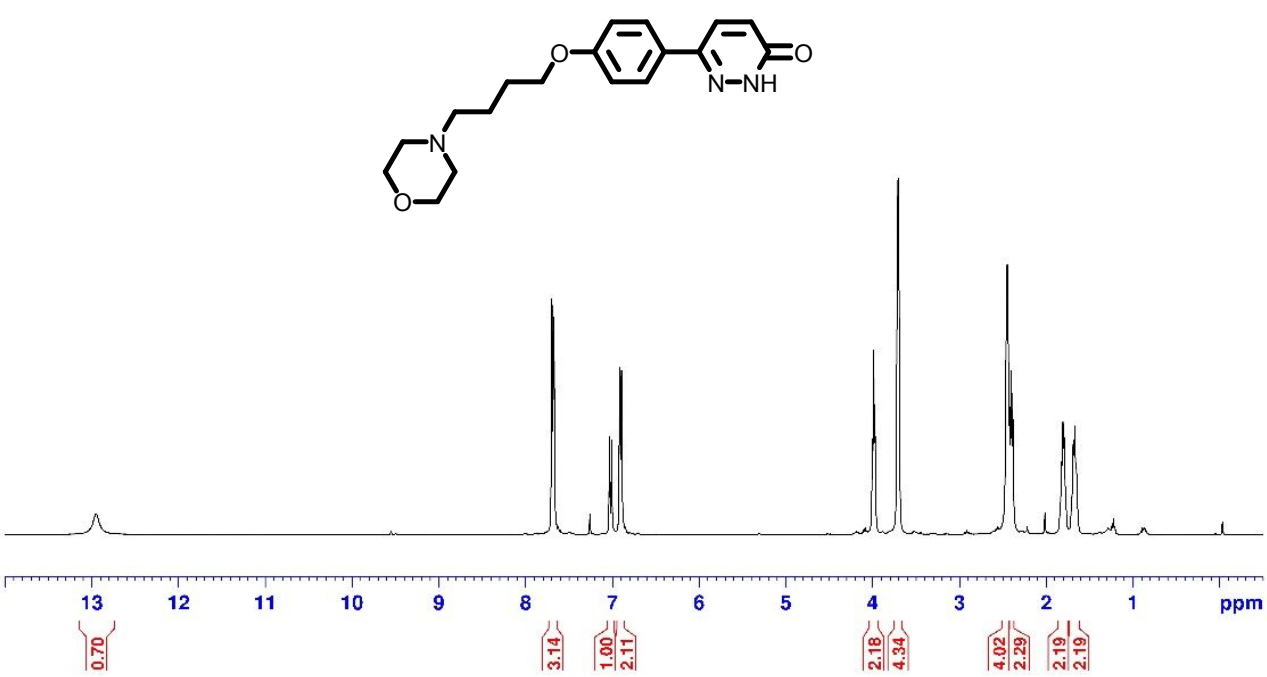

${ }^{1} \mathrm{H}$ NMR spectrum of compund 12 in $\mathrm{CDCl}_{3}$

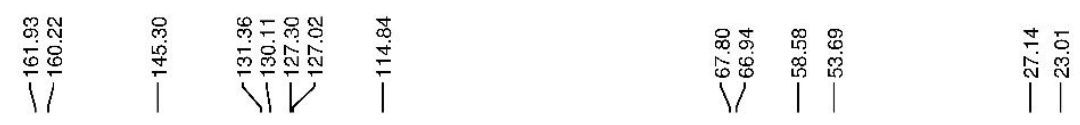

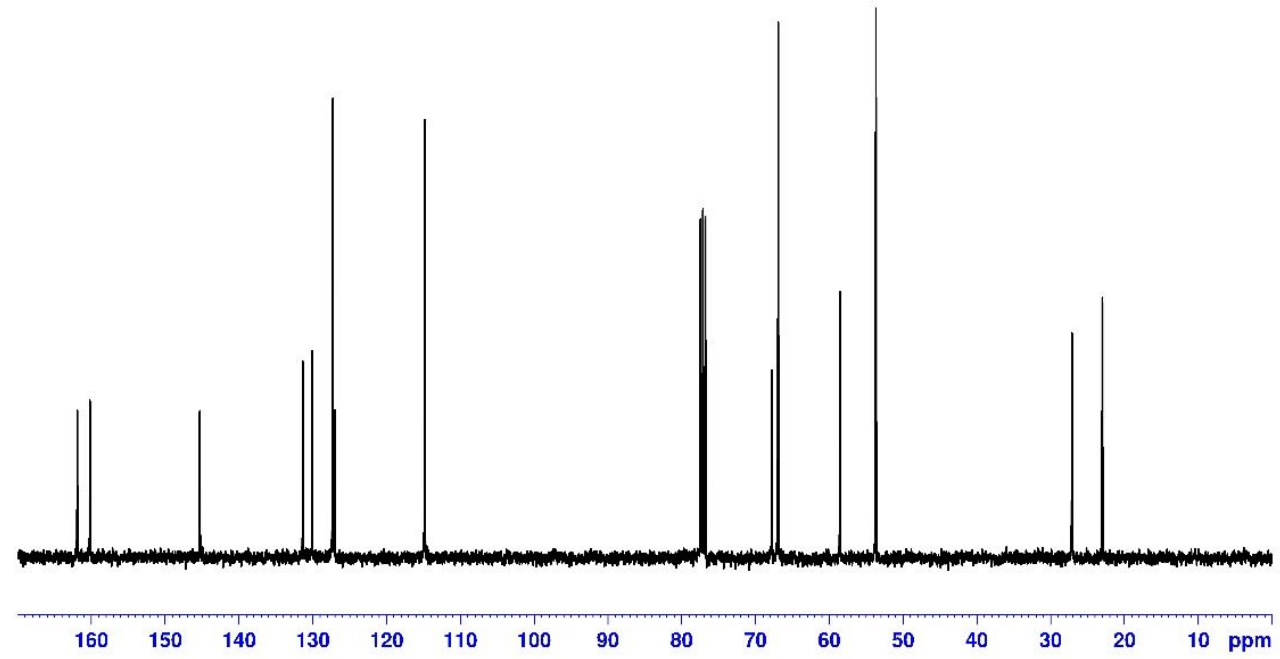

${ }^{13} \mathrm{C}$ NMR spectrum of compund 12 in $\mathrm{CDCl}_{3}$ 


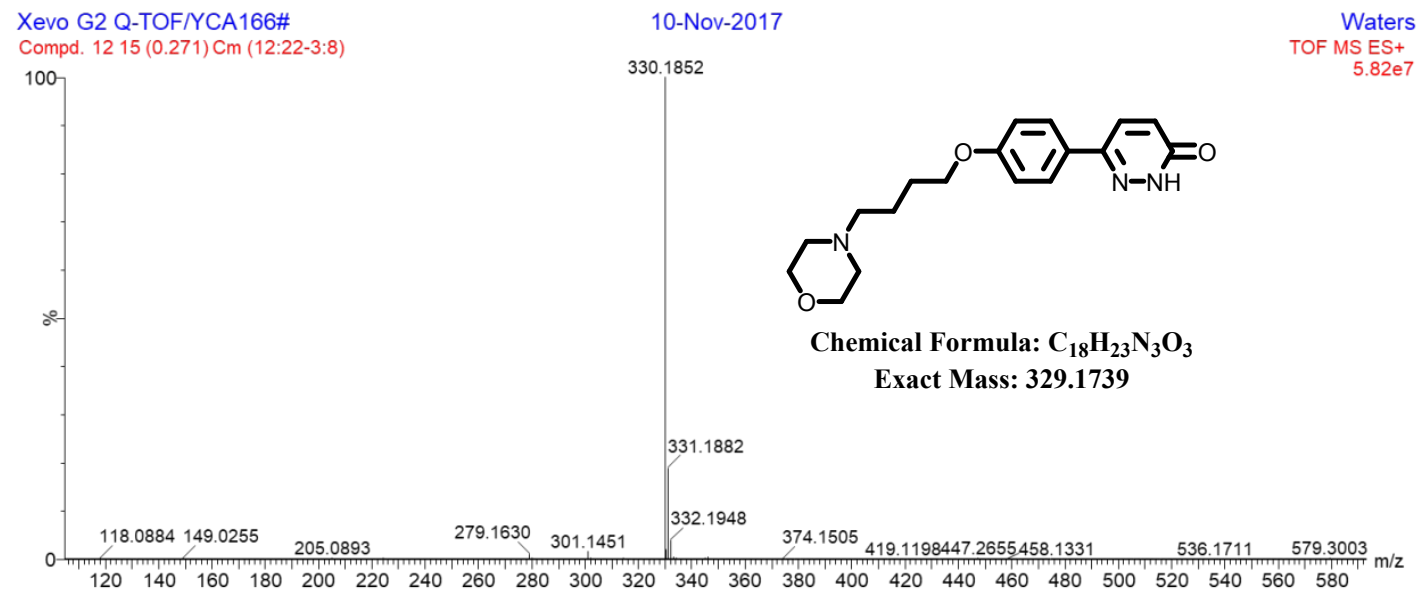

HRMS spectrum of compund $\mathbf{1 2}$ 


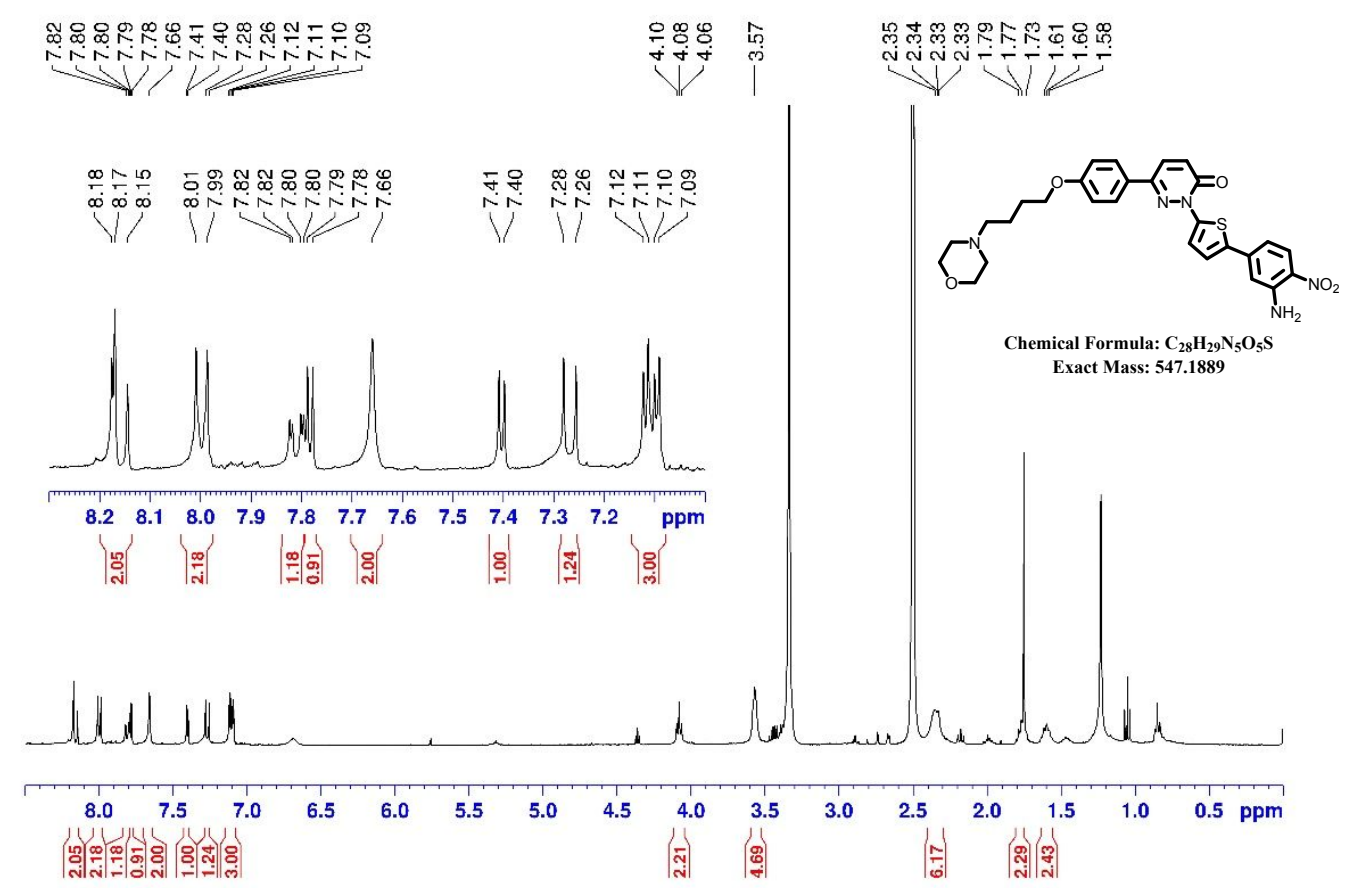

${ }^{1} \mathrm{H}$ NMR spectrum of compund 13 in DMSO- $d_{6}$

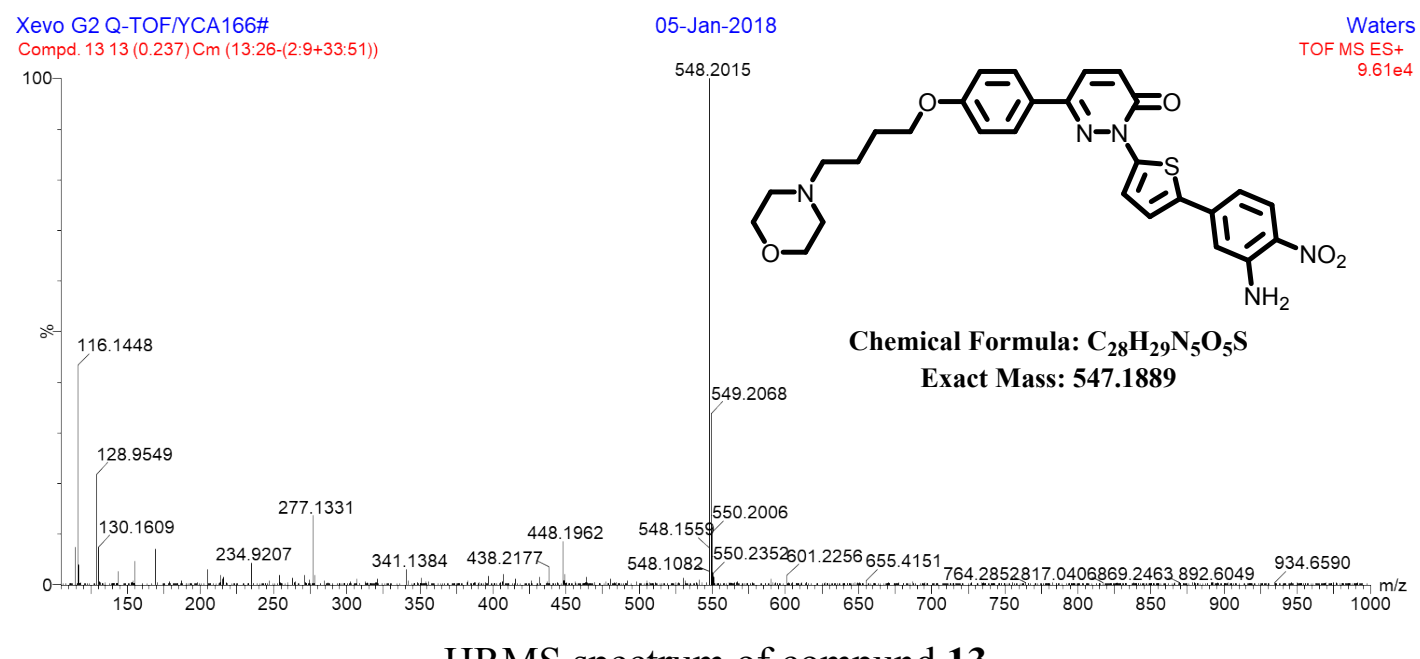

HRMS spectrum of compund $\mathbf{1 3}$ 


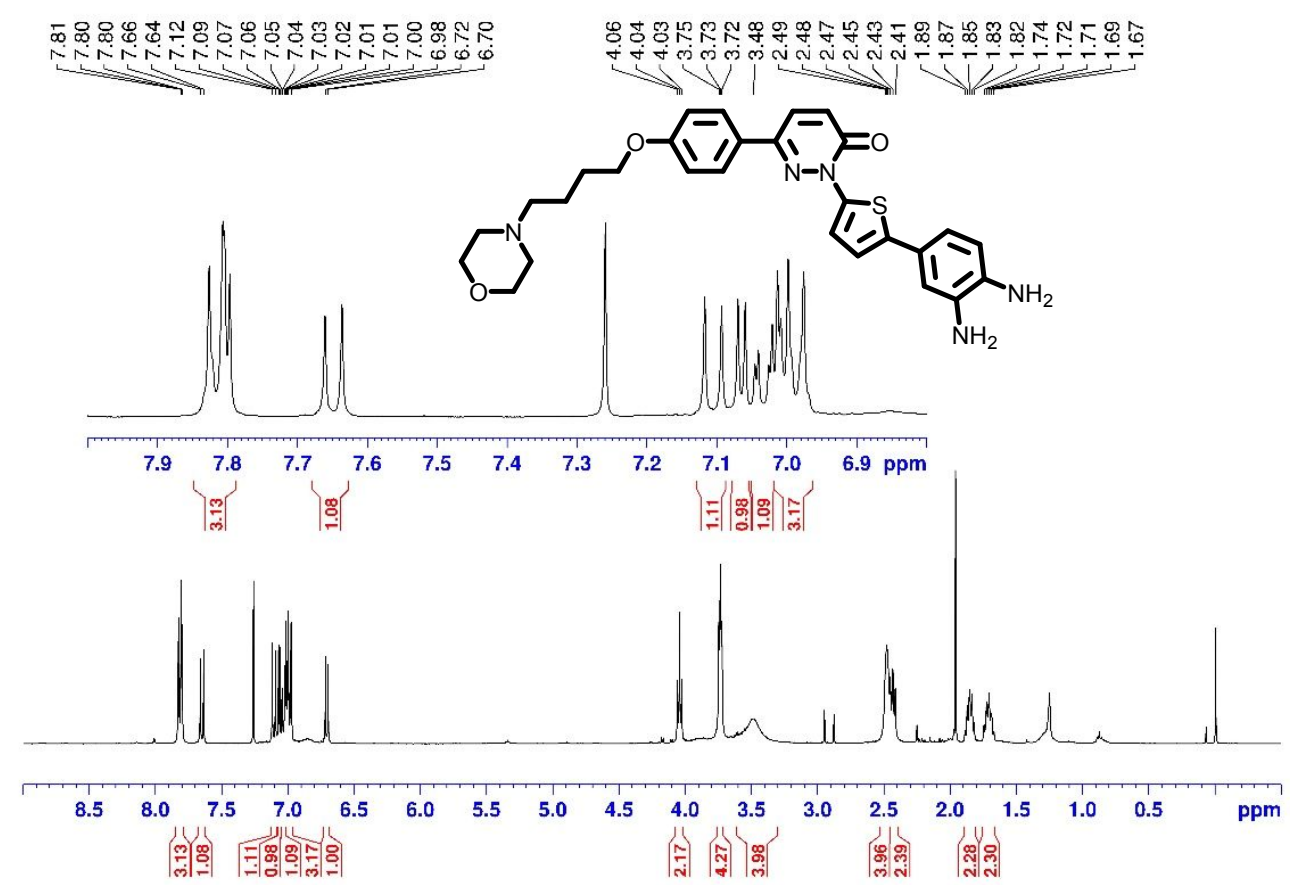

${ }^{1} \mathrm{H}$ NMR spectrum of PYSNO in $\mathrm{CDCl}_{3}$

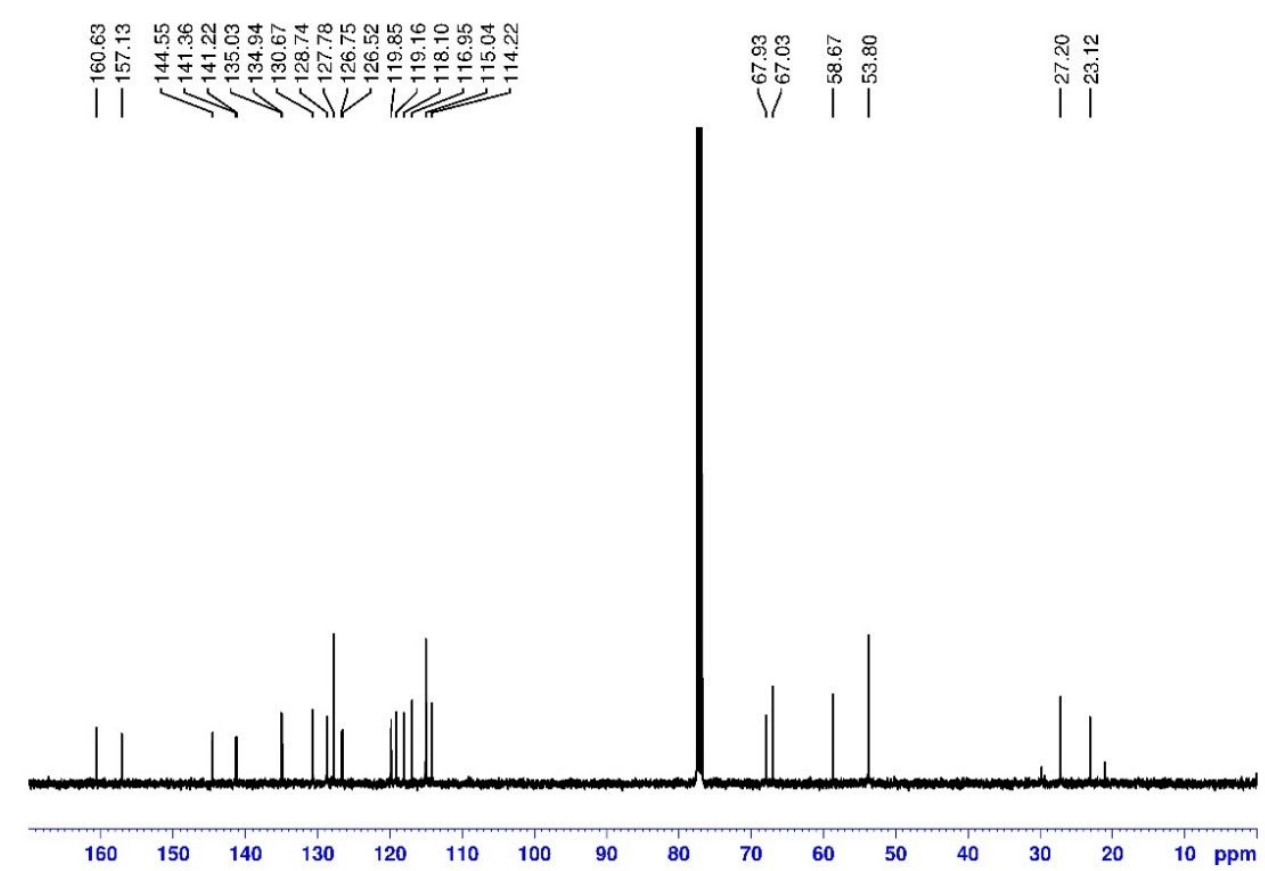

${ }^{13} \mathrm{C}$ NMR spectrum of PYSNO in $\mathrm{CDCl}_{3}$ 
Xevo G2 Q-TOF/YCA166\#

Compd. PYSNO $17(0.324) \mathrm{Cm}(13: 24-(3: 7+35: 55))$

100

$-1$

$3782343408.2302 \quad 4182253 \quad 431.2185 \quad 475.2185 \quad 518.1508 \quad 521.2256540 .2042$

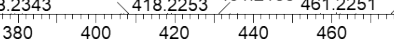

05-Jan-2018 518.2217

Waters

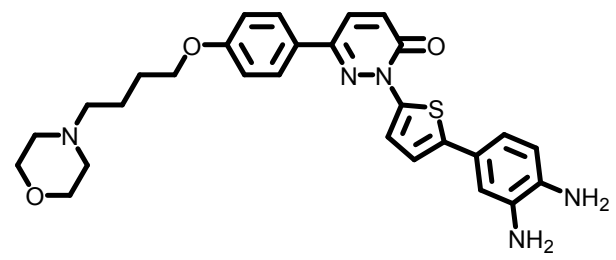

Chemical Formula: $\mathrm{C}_{28} \mathrm{H}_{31} \mathrm{~N}_{5} \mathrm{O}_{3} \mathrm{~S}$ Exact Mass: 517.2148

\section{HRMS spectrum of PYSNO}




\section{References}

(1) Zhou, T.; Yang, L.; Liang, L.; Liu, H.; Zhu, Y.; Shui, M.; Yuan, L.; Xu, F.; Niu, Y.; Wang, C.; Xu, P. Rational Design of a Near-Infrared Fluorescent Probe Based on a Pyridazinone Scaffold. Eur. J. Org. Chem. 2017, 22, 3274-3281.

(2) Peng, T.; Wong, N.; Chen, X.; Chan, Y.; Ho, D. H.; Sun, Z.; Hu, J. J.; Shen, J.; ElNezami, H.; Yang, D. Molecular Imaging of Peroxynitrite with HKGreen-4 in Live Cells and Tissues. J. Am. Chem. Soc. 2014, 136, 11728-11734.

(3) Li, X.; Tao, R. R.; Hong, L. J.; Cheng, J.; Jiang, Q.; Lu, Y. M.; Liao, M. H.; Ye, W. F.; Lu, N. N.; Han, F.; Hu, Y. Z.; Hu, Y. H. Visualizing Peroxynitrite Fluxes in Endothelial Cells Reveals the Dynamic Progression of Brain Vascular Injury. J. Am. Chem. Soc. 2015, 137, 12296-12303.

(4) Karstens, T.; Kobs, K. Rhodamine B and Rhodamine 101 as Reference Substances for Fluorescence Quantum Yield Measurements. J. Phys. Chem. 1980, 84, 1871-1872.

(5) Song, J.; Zhang, D.; Liu, Y.; Zhao, Y.; Ye, Y. A Highly Sensitive and Selective Turn-On Fluorescent Probe for Sulfite and Its Application in Biological Imaging. New J. Chem. 2015, 39, 6284-6288.

(6) Li, Z.; Li, X.; Gao, X.; Zhang, Y.; Shi, W.; Ma, H. Nitroreductase Detection and Hypoxic Tumor Cell Imaging by a Designed Sensitive and Selective Fluorescent Probe, 7-[(5-Nitrofuran-2-yl)methoxy]-3H-phenoxazin-3-one. Anal. Chem. 2013, 85, 39263932.

(7) Chen, W.; Li, Z.; Shi, W.; Ma, H. A New Resorufin-Based Spectroscopic Probe for Simple and Sensitive Detection of Benzoyl Peroxidevia Deboronation. Chem. Commun. 
2012, 48, 2809-2811.

(8) Cheng, J.; Song, J.; Niu, H.; Tang, J.; Zhang, D.; Zhao, Y.; Ye, Y. A New RosamineBased Fluorescent Chemodosimeter for Hydrogen Sulfide and Its Bioimaging in Live Cells. New J. Chem. 2016, 40, 6384-6388.

(9) Ishiyama, M.; Miyazono, Y.; Sasamoto, K.; Ohkura, Y.; Ueno, K. A Highly WaterSoluble Disulfonated Tetrazolium Salt as a Chromogenic Indicator for NADH as well as Cell Viability. Talanta, 1997, 44, 1299-1305. 